Article

\title{
Integrated Modeling of Water Supply and Demand Under Climate Change Impacts and Management Options in Tributary Basin of Tonle Sap Lake, Cambodia
}

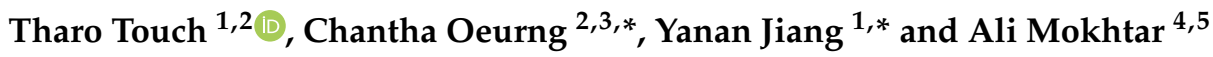 \\ 1 College of Water Resources and Architectural Engineering, Northwest A\&F University, \\ Yangling 712100, China; tharo.touch@yahoo.com \\ 2 Faculty of Hydrology and Water Resources Engineering, Institute of Technology of Cambodia, \\ Phnom Penh 12156, Cambodia \\ 3 Department of Landscape Architecture and Environmental Planning, University of California, \\ Berkeley, CA 94720, USA \\ 4 State of Key Laboratory of Soil Erosion and Dryland Farming on Loess Plateau, Institute of Soil and Water \\ Conservation, Northwest A\&F University, Chinese Academy of Sciences and Ministry of Water Resources, \\ Yangling 712100, China; Ali.mokhtar@agr.cu.edu.eg \\ 5 Department of Agricultural Engineering, Faculty of Agriculture, Cairo University, Giza 12613, Egypt \\ * Correspondence: chantha@itc.edu.kh (C.O.); yananjiang@nwafu.edu.cn (Y.J.)
}

Received: 2 July 2020; Accepted: 28 August 2020; Published: 2 September 2020

check for updates

\begin{abstract}
An integrated modeling approach analyzing water demand and supply balances under management options in a river basin is essential for the management and adaptive measures of water resources in the future. This study evaluated the impacts of climate change on the hydrological regime by predicting the change in both monthly and seasonal streamflow, and identified water supply and demand relations under supply management options and environmental flow maintenance. To reach a better understanding of the consequences of possible climate change scenarios and adaptive management options on water supply, an integrated modeling approach was conducted by using the soil and water assessment tool (SWAT) and water evaluation and planning model (WEAP). Future scenarios were developed for the future period: 2060s (2051-2070), using an ensemble of three general circulation model (GCM) simulations: GFDL-CM3, GISS-E2-R-CC, and IPSL-CM5A-MR, driven by the climate projection for representative concentration pathways (RCPs): 6.0 (medium emission scenario). The results indicated that, firstly, the future streamflow will decrease, resulting in a decline of future water availability. Secondly, water supply under natural flow conditions would support 46,167 ha of irrigation schemes and the water shortages will be more noticeable when environmental flow maintenance was considered. The study concludes that reservoir construction would be necessary for agriculture mitigation and adaptation to climate change. Furthermore, the water resources management options considering both supply and demand management are more effective and useful than supply management only, particularly in dealing with climate change impacts.
\end{abstract}

Keywords: integrated model; climate change; streamflow; SWAT model; WEAP model; water demand; water shortage; management option

\section{Introduction}

Water resources have been increasingly stressed due to the growth of multiple pressures, such as climate change, population growth, groundwater depletion, energy demand rise, and environmental 
flow requirements [1,2]. The Intergovernmental Panel on Climate Change (IPCC) has recognized the significant indications of climate change: global temperature rise due to greenhouse emissions and water cycle changes [3]. IPCC uses general circulation models (GCMs) for future climate change projections based on different representative concentration pathways (RCPs) scenarios. GCM projections indicate a strong variability of future precipitation and temperatures in terms of trends and extremes [4]. The change in the water cycle and hydrological regime would result from land use/cover change and climate change. Regarding future water management and hydrological processes under climate change conditions, water availability for meeting water supply diversion, reservoir storage, and environmental flow requirements must be assessed [5]. River flow maintenance is essentially needed for sustaining biodiversity in a river's ecosystem. Water demand increases generally result unsustainable water use and insufficient water remain for environmental conservation [6]. In order to alleviate the water shortage problem, management options have been introduced as a key suggestion for water resources management. Management options could be considered both demand (reduce water demand) and supply (increase water to fulfill the demand) management options.

Along with the geographical and ecological factors, the water management options are also determined by the human and social conditions. Zhou and Ching [7] provided an empirical grounding for how institutional entrepreneurship could change the relationship between institutions and actor's ability. This case analysis could be applied to understanding water management options in Cambodia as negotiating the tensions and interactions between institutions and key narrative actors. Additionally, Leong [8] provided a different key perspective on the various pressures affecting Cambodia's water governance, such as that of institutional and social networks, and policy efficacy. Similarly, Dore and Lebel [9] concluded that water governance in the Mekong region could further illustrate the extent and complexity of Cambodia's water governance in relation to the rest of the region. The combined impacts of hydrological alterations, human and social conditions on water governance are complex and challenging in most vulnerable regions.

The tropical regions are particularly influenced by the impacts of climate change on agricultural productivity, water and natural resources accessibility [10]. Developing countries in tropical regions (e.g., Cambodia) demonstrate a heavy reliance on climate-sensitive natural resources, i.e., economies largely depend on agriculture [11,12]. South East Asian countries, located in a tropical region, are highly vulnerable to the impacts of climate change. Cambodia is particularly vulnerable among those countries [13]. The Tonle Sap lake is a main tributary of the lower Mekong river and is also a main water source of Cambodia economic development in many sectors, particularly the agricultural sector. However, water resources management in tributary of Tonle Sap lake is increasingly under pressure due to the increase of paddy rice productions, the diversion of irrigated water in the dry season, inadequate irrigation infrastructures, and climate change impacts. Hence, this study considered the tributary of Tonle Sap lake as the research area.

Irrigated agriculture is the largest water consumer in Cambodia. Besides the increasing irrigation demand through agriculture land expansion, climate change also has significant impacts on irrigation requirement. The effects of climate change on irrigation requirements are highly sensitive to temperature and precipitation variations $[14,15]$. Previous studies have used GCMs to identify the likely effects of climate change on the water supplies and demands for agriculture by altering the hydrological cycle $[4,16,17]$. The changes in hydrological regime, i.e., water supplies in the Lower Mekong and the Tonle Sap Lake basin, were widely discussed in various studies $[18,19]$. However, most studies only focused on the large scale, with results showing overall parallel responses to future climates, i.e., projected rainfall increases in the whole basin. Uncertainties associated with local and regional climate change impacts on precipitation are still high [20], which therefore, lead to inaccuracy results of future projections. In addition, the authors only focused the climate change impacts on the water availability, i.e., streamflow, rather than water demand, i.e., irrigation water demand. Thus, the assessment of water supply and demand relations through different scenario evaluations in the tributary basin of Tonle Sap lake will be considered in this paper. Facing these challenges, an integrated 
modeling framework has been introduced as a key tool to understand hydrology processes for the present and future predictions.

Integrated model simulations are necessarily needed to quantify the balance between water supply and demand [21,22]. In order to achieve sustainable water resources management, the integrated watershed management concepts have been well recognized [2,23]. In contrast, quantitative assessment tools are inadequate to guide local water resources managers. Water resource management and planning models have been emerging to analyze water balance in the watershed and optimize reservoir operations. However, these models are limited to examine runoff process and analyze other hydrological components including evapotranspiration (ET) on a physical basis for different land uses [22]. The soil and water assessment tool (SWAT) model [24] is capable of simulating runoff and other hydrological components on a physical basis. However, conventional water supply-oriented simulation models are often insufficient for identifying contemporary water resources management problems [25]. A comprehensive integrated modelling approach is therefore very useful to achieve sustainable water resources managements considering hydrological responses to climate changes, water resources allocation and agriculture economy.

Therefore, the study attempted to examine the impacts of climate change on hydrological regime over the Pursat River Basin (PRB), and to identify water supply and demand relation under supply management options and environmental flow conservations. Moreover, this research raised three questions: (1) How does climate change impact on hydrological regime? (2) To what extent will the presence of reservoir be substantial benefit to the water supply for alleviating water shortages problem? (3) How do supply management measures, through constructing more reservoirs, interrelate with climate change impacts? This paper would provide a technical evidence for the basic values of water management model integration for decision making and policy planning for ensuring sustainable water resources management in highly stressed regions under climate change scenarios.

\section{Materials and Methods}

\subsection{Study Area}

The Pursat River Basin is located in Pursat Province south of Tonle Sap Great Lake, with a total catchment of $59,55 \mathrm{~km}^{2}$ (Figure 1a). Climate is dominated by tropical monsoon systems with distinct wet and dry seasons [26], the average annual temperature is $28^{\circ} \mathrm{C}$ (Figure 2a) and the average annual rainfall ranges from $1200 \mathrm{~mm}$ in the lowest part to $1700 \mathrm{~mm}$ in the upper part (Figure 2b) [27]. Moreover, the wet season starts from May to November and the dry season extends from December to April [26]. The elevation ranges between $6 \mathrm{~m}$ and $1745 \mathrm{~m}$ above sea level, in which the majority of the catchment encompasses the mountainous area, with an elevation greater than $30 \mathrm{~m}$ above sea level, and is covered by forested land of varying densities (Figure 1b). The remaining low-lying land is occupied by agricultural land, rural and urban livelihood (Figure 1b). The eastern slopes of the Cardamom mountains is where the river originates, and the river flows for about $150 \mathrm{~km}$, directly draining annual, discharge of about 2818 million cubic meters (MCM) into the Tonle Sap Great Lake [28]. The Stung Peam and Stung Santre (Prey Khong) rivers are two main river tributaries which flow into the Pursat river in a northerly direction above Bac Trakuon [26]. Major soil types in the PRB are Dystric Leptosol and Cambisol in the upper reaches; Gleyic and Plintic Acrisol in the mid-elevation reaches; Dystric Fluvisol and Dystric Gleysol in the lower elevation reaches (Figure 1c) [28]. The land cover is dominated by forest land (76.2\%), agricultural land (23.8\%), and Urban land (0.1\%) [29]. Forests and natural vegetation occupied over $73 \%$ of the province, approximately 438,641 ha [30]. Three main forest distributions: deciduous, evergreen and semi-evergreen forests were 130,830 ha, 238,478 ha, and 69,333 ha, respectively (Figure 1d) [26]. The irrigation constructions in the PRB mainly include reservoir, pond, pumping, and dams (Table 1). There are 17 large and medium-sized existing and planned irrigation scheme projects, including 3 in the Svay Donkeo river basin (neighboring catchment), which cover an area of 55,509 ha [31]. The locations of all existing and planned irrigation structures in the PRB and 
neighboring catchment are shown in Figure 1a. Dam No.3 and No. 5, funded by Chinese institutions, were constructed in 2010 and went to full operation in 2014. Dam No.3 and Dam No.5 have storage capacities of 25.5 MCM and 24.5 MCM, respectively (Figure 1a) [32]. The feasibility study of Dam No.1 construction is being conducted by the Ministry of Industry Mines and Energy (MIME) with technical support from the Korean Government [33]. Dam No.1 is designed as a multi-purpose dam with storage capacity in excess of 1000 MCM. Moreover, it is a hydropower dam for electricity generation and a reservoir storage for water irrigation in dry season. A summary of the hydropower dam and reservoir characteristics in the PRB is presented in Table 2 followed by a description of the major projects.

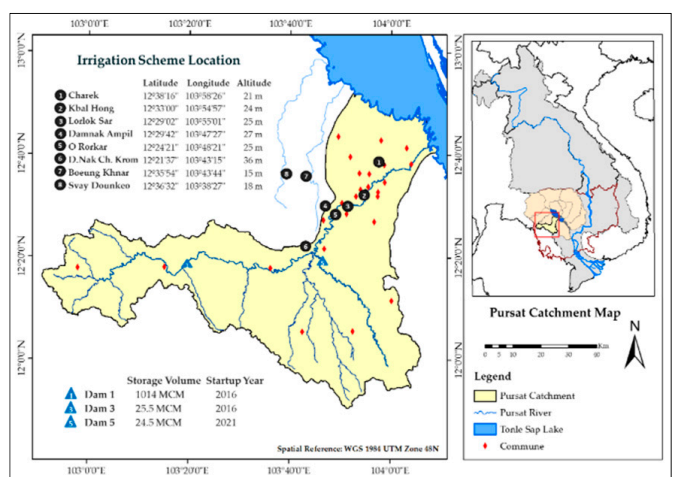

(a)

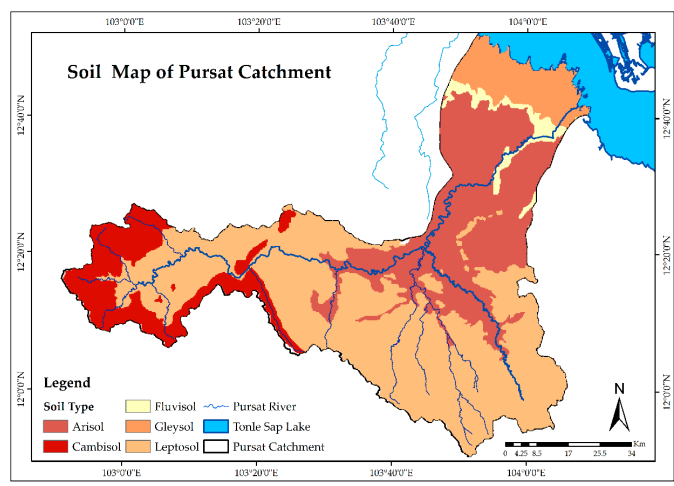

(c)

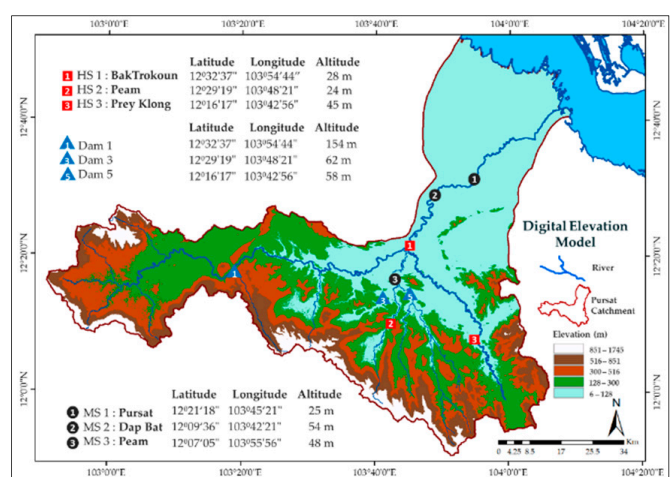

(b)

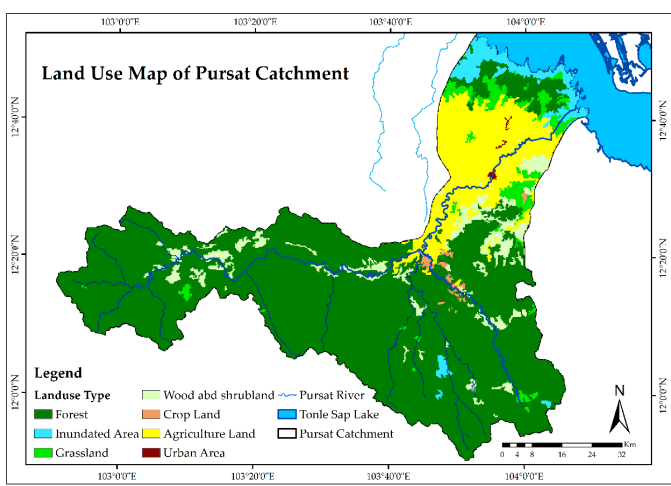

(d)

Figure 1. (a) Study area with dam and irrigation scheme location, (b) digital elevation model with hydrological and meteorological station, (c) soil type, (d) land use/land cover of PRB.

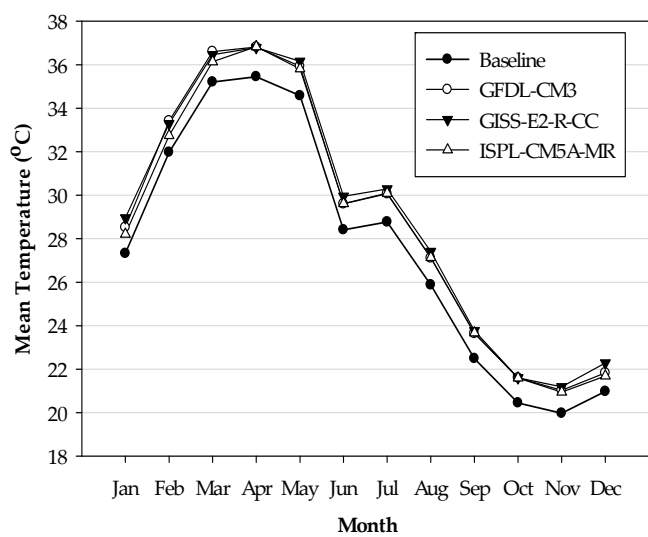

(a)

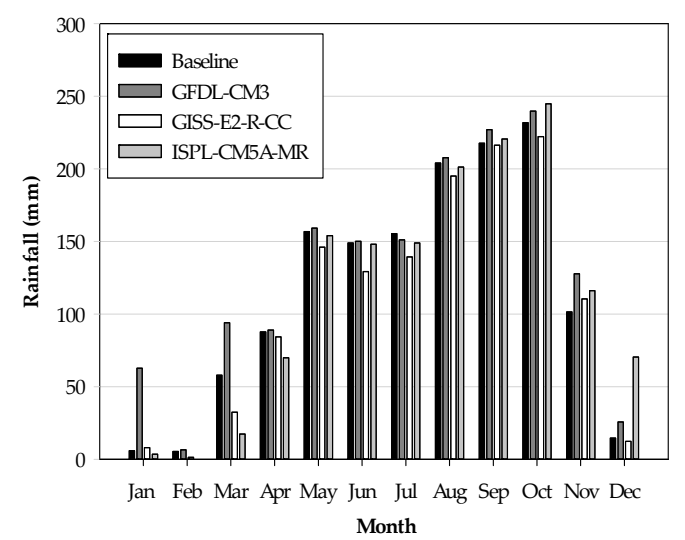

(b)

Figure 2. (a) Mean monthly temperatures and (b) mean monthly precipitation for baseline (1982-2010) and future (2051-2070) period. 
Table 1. The characteristics of the Hydropower Dam No.1, Reservoir Dam No.3 and Reservoir Dam No.5.

\begin{tabular}{cccc}
\hline Hydropower Dam and Reservoir Characteristics & Dam No. 1 & Dam No.3 & Dam No.5 \\
\hline Rated Gross Head $(\mathrm{m})$ & 122 & - & - \\
Installed Capacity (MW) & 40 & - & - \\
Overall Efficiency at Gross Head (-) & 0.9 & - & - \\
Full Supply level (m asl) & 195 & - & - \\
Low Supply level (m asl) & 170 & - & - \\
Tail Water Level $\left(\mathrm{m} \mathrm{asl}^{2}\right.$ & 65 & - & - \\
Design Discharge $\left(\mathrm{m}^{3} / \mathrm{s}\right)$ & 38.8 & - & - \\
Live Storage $\left(\mathrm{m}^{3} \times 10^{6}\right)$ & 1014 & 24.5 & 25.5 \\
Dead Storage $\left(\mathrm{m}^{3} \times 10^{6}\right)$ & 306 & - & - \\
\hline
\end{tabular}

$\mathrm{m}$ : meter; MW: megawatt; $\mathrm{m}$ asl: meter above sea level; $\mathrm{m}^{3} / \mathrm{s}$ : cubic meter per second and $\mathrm{m}^{3} \times 10^{6}$ : million cubic meters.

Table 2. Summary of irrigation scheme projects with command area in the PRB.

\begin{tabular}{cccc}
\hline Irrigation Scheme & Command Area (ha) & Existing & Planned \\
\hline Damnak Cheukrom & 16,100 & - & Yes \\
Damnak Ampil extension & 7500 & Yes & Yes \\
Damnak Ampil & 2519 & - & Yes \\
Orokar & 4700 & Yes & - \\
Loloksar & 580 & Yes & - \\
Wat Loung & 2410 & - & Yes \\
Kbal Houng (right bank) & 1200 & Yes & - \\
Kbal Houng (left bank) & 2000 & Yes & - \\
Charek & 11,000 & Yes & - \\
Svay Doun Keo & 815 & Yes & Yes \\
Boeung Khnar & 6714 & Yes & Yes \\
Total command area & 55,538 & & \\
\hline
\end{tabular}

\subsection{Intergrated Model Approach}

The SWAT-WEAP integration approach was conducted to technically assess the impact of climate change on water regime and extensive water resources management options (Figure 3). The SWAT model was adopted to the supply side of water resources and mainly used to simulate the incoming flows of those tributaries without observation (i.e., no hydrological monitoring stations) in the PRB [24]. The SWAT model was calibrated and validated using observed streamflow data (2003-2011) from the Bak Trakoun hydrological station in previous study [34]. The future climate data, downscaled by Mekong River Commission (MRC), were input to SWAT to simulate the future change in streamflow under climate change scenarios derived from different climate models. According to Yates et al. [25], the water availability of each sub-basin generated by SWAT was input to the WEAP model, thus the supply and demand relations under different water use patterns could be evaluated. The future climate data were also used to calculate the future change in reference evapotranspiration and effective rainfall for future period (2051 to 2070) (Figure 2). The data of irrigated area, domestic and industrial site, irrigation water requirement, and streamflow in both current and future status were driven into WEAP model. Current and future climate scenarios including supply management options were created in WEAP model to examine the water supply and demand relations through water management analysis and scenario evaluation. The integrated method was applied to simulate the current and future status (2016-2025 and 2051-2070) of water resources scenario. The SWAT model was successfully calibrated and validated using experiential streamflow data from 2003 to 2011 [34]. The results indicated that SWAT can accurately simulate the PRB streamflow characteristics. In this article, the results were mainly focused on future changes in streamflow and water balance simulations in the WEAP model. 


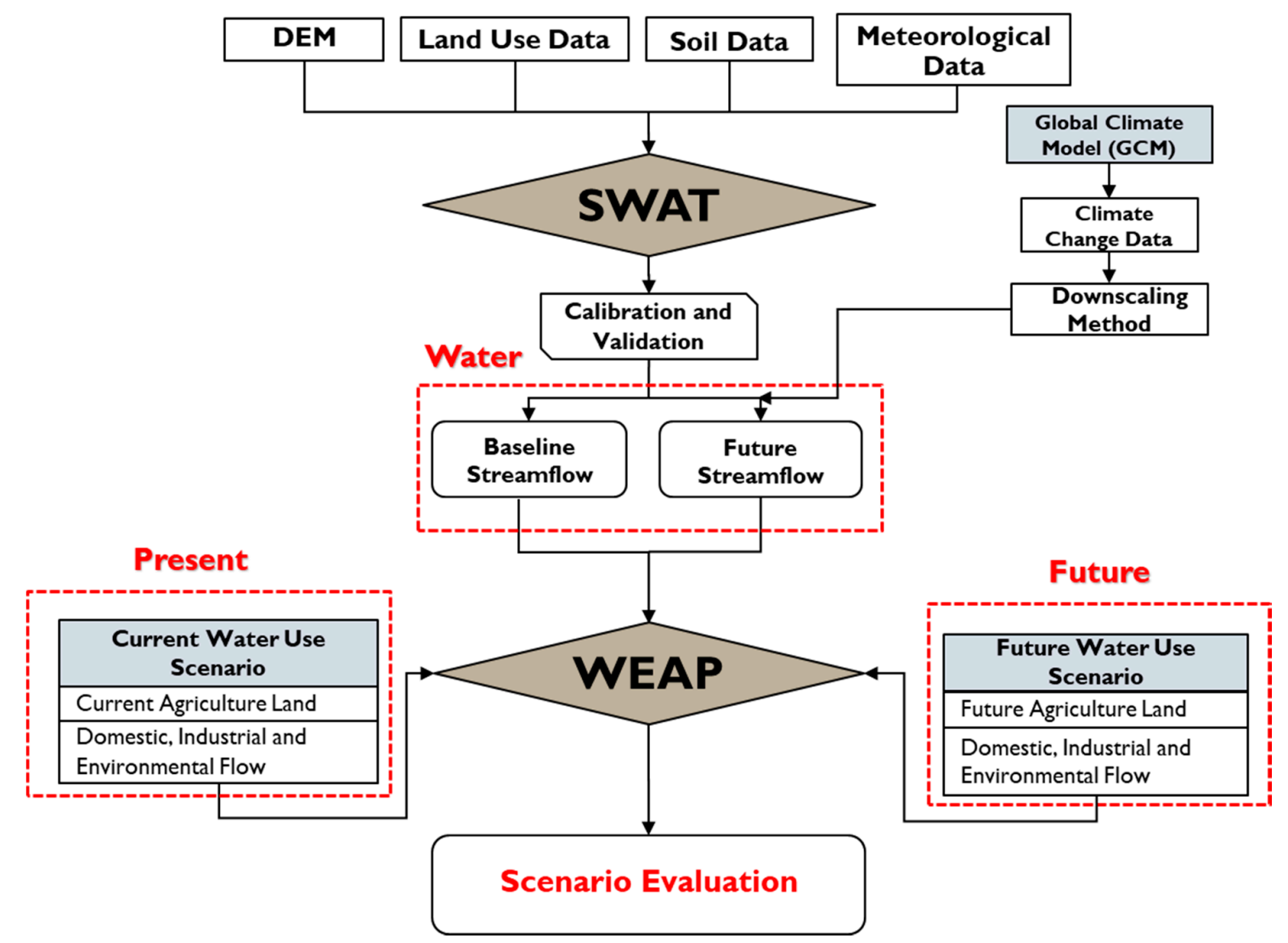

Figure 3. Model flowchart that illustrates the integration of the Soil and Water Assessment Tool (SWAT) and Water Evaluation and Planning (WEAP) models.

\subsection{Data and Model Parameterization}

Data required by SWAT model to simulate monthly discharge consisting of Digital Elevation Model (DEM), land use, soil, and meteorological data. Sub-basins were delineated by using DEM with 30m-resolution obtained from ASTER Global DEM Version 2 released by the Ministry of Economy, Trade, and Industry (METI), Tokyo, Japan and the United States National Aeronautics and Space Administration (NASA), Washington, D.C., United States. Land use and soil data with 250 m-resolution (2002) were provided by MRC. The daily meteorological and flow data from 2002 to 2011 were acquired from Department of Hydrology and River Work of Ministry of Water Resources and Meteorology of Cambodia (MOWRAM). As shown in Table 3, there is a good agreement between observed and simulated flows based on criteria of three statistical indicators (NSN, PBIAS, and RSR). Additional data consisting of the water extraction locations, water demand sites and orders of water linkage, and water diversion and supply/demand were acquired from a field survey (Figure 4) [31]. Meteorological data from 1982 to 2010 consisted of maximum and minimum temperature, humidity, sunshine hours, and wind speed data with grid of $0.25^{\circ}$ spatial resolution, and observed daily rainfall at three rainfall stations: Peam, Pursat, and Dap Bat over the PRB. The observed monthly streamflow at Bak Trakoun station were required by SWAT-CUP to make a calibration from 2003 to 2008 and a validation from 2009 to 2011 (Figure 5) [34]. 
Table 3. Calibration and validation performance for monthly time-step streamflow simulations at the PRB showing the Nash-Sutcliffe efficiency (NSE), percent bias (PBIAS), root mean squared error observations standard deviation ratio (RSR).

\begin{tabular}{ccccccc}
\hline Station Name & \multicolumn{3}{c}{ Calibration (2001-2008) } & \multicolumn{3}{c}{ Validation (2009-2011) } \\
\hline \multirow{2}{*}{ Bak Trokoun } & NSE & PBIAS & RSR & NSE & PBIAS & RSR \\
& 0.59 & 1.15 & 0.63 & 0.55 & 1.2 & 0.85 \\
\hline
\end{tabular}

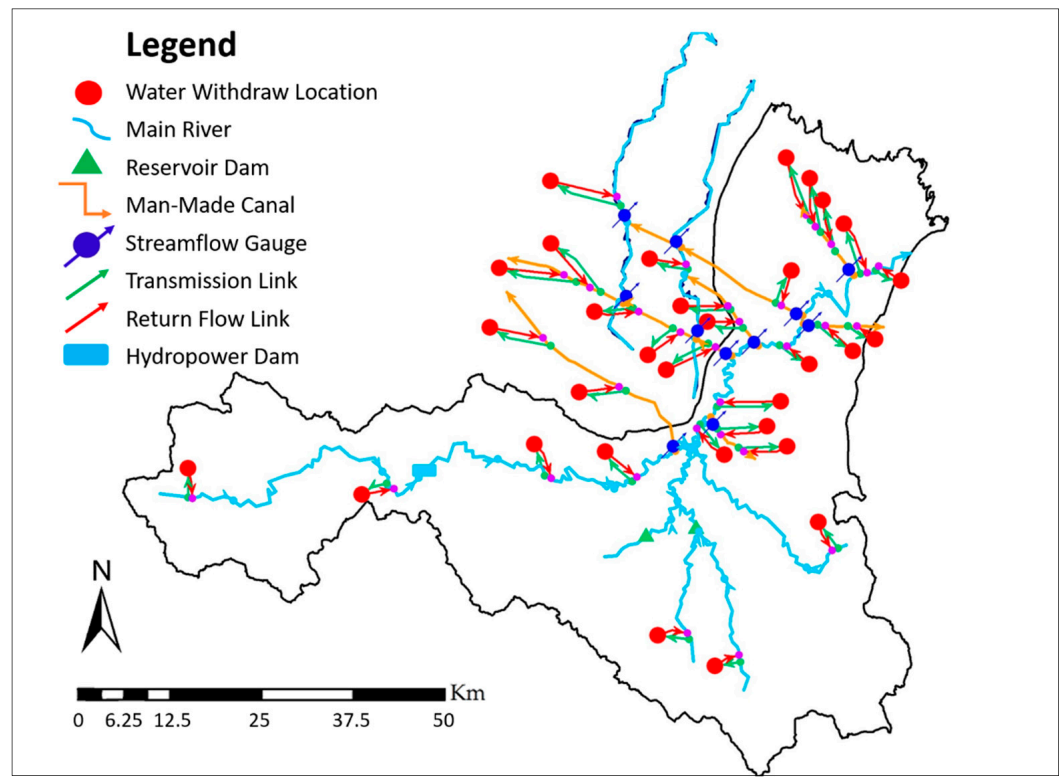

Figure 4. The schematic view of the Pursat River Basin (PRB) on WEAP model interface illustrated the hydrologic and infrastructural connections after adding three reservoirs. A physical component such as a water withdrawal point, or main water-use location along a river system are viewed by rounded red notes. Each node is linked by lines that represent the natural or artificial water networks such as river channels and man-made canals. These lines consist of rivers, water diversion, transmission links, and return flow links. A river reach is defined as the section of a river or diversion between two river nodes. Elements in the schematic of the PRB: River, Diversion, Streamflow Gauge, Agricultural Demand Site, Domestic Demand Site in Pursat urban; Domestic Demand Site in Pursat suburbs and rural; Industrial Demand Sites; added reservoirs: Dam 1, Dam 2 and Dam 3.

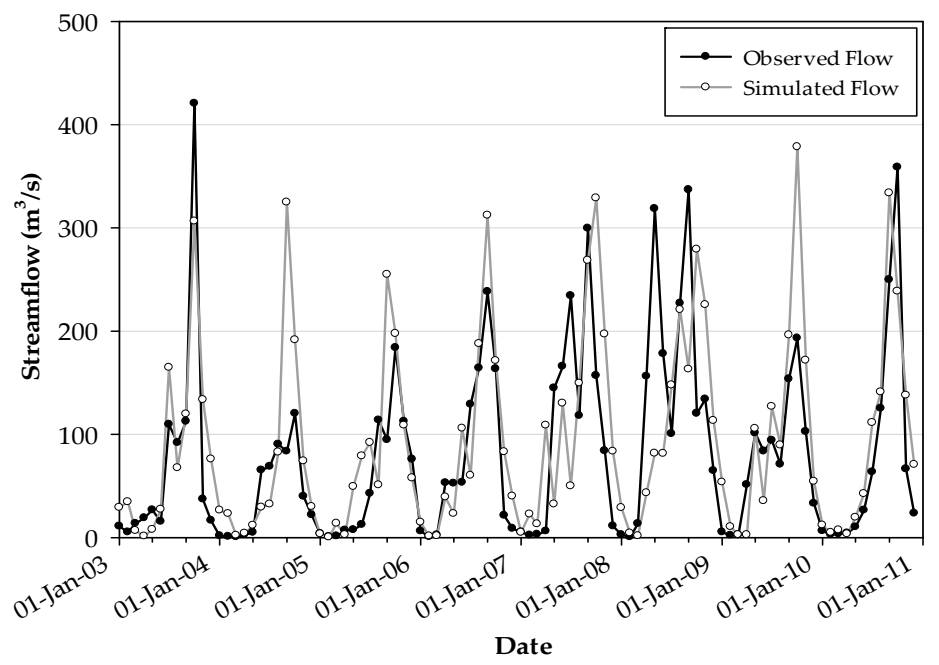

Figure 5. Comparison between monthly simulated and observed streamflow. 
Irrigation water demand (IWD) for proposed cropping pattern of each crop variety were estimated based on the equation following by Japan International Cooperation Agency (JICA) (Equation (1)) [35]. The combination of proposed cropping patterns studied by JICA and MOWRAM [31] was used in this study (Table 4). Paddy rice, both rain-fed and irrigated, consisting of seven cropping patterns were selected as the major crop types. As recommended by the Food and Agriculture Organization (FAO) [36], the standard crop coefficients of each crop stage of paddy rice were used to calculate the crop water requirement. In addition, the values of Reference Evapotranspiration $\left(\mathrm{ET}_{0}\right)$ for baseline and climate change scenario were calculated by Blaney-Criddle method [37] (Equation (2)) along with long-time meteorological data from 1982 to 2010 . The effective rainfall was calculated using the formula proposed by JICA (Equation (3)). Irrigation areas for each cropping pattern, as well as a crop calendar for the Stung Pursat catchment are shown on Table 4. The unit of baseline and future irrigation water requirement of each crop type are shown in Figure 6.

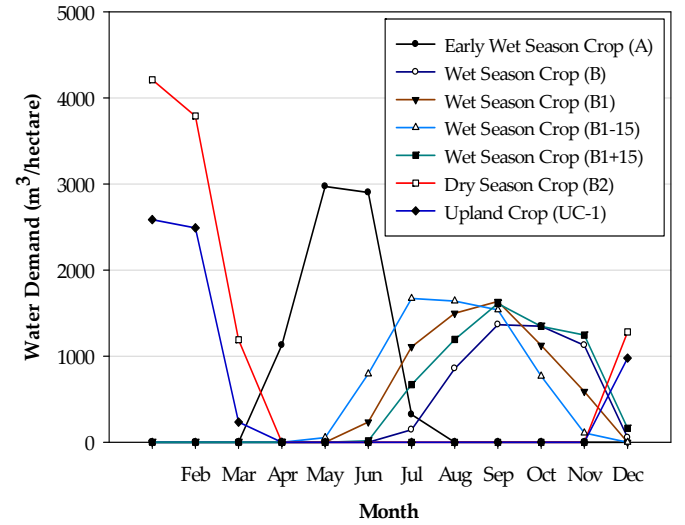

(a)

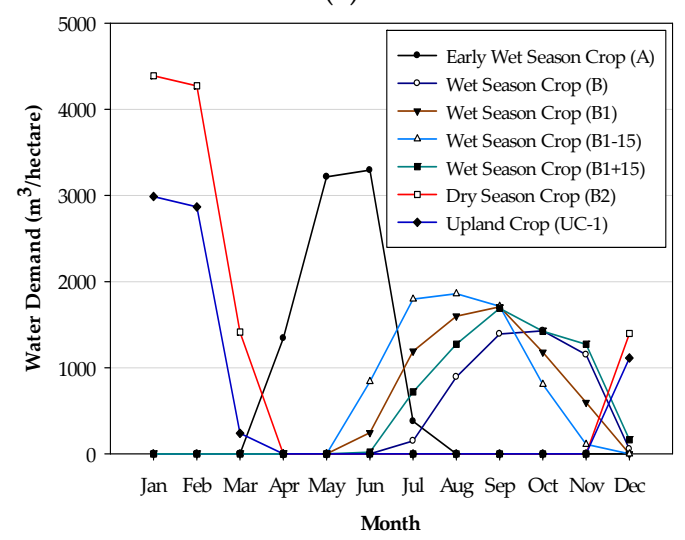

(c)

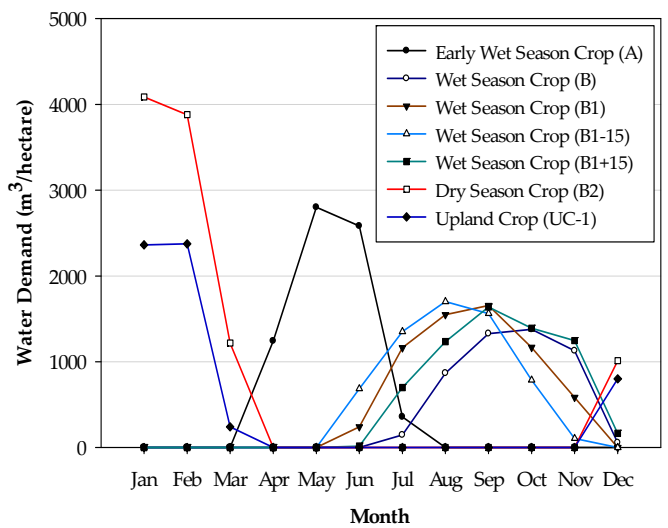

(b)

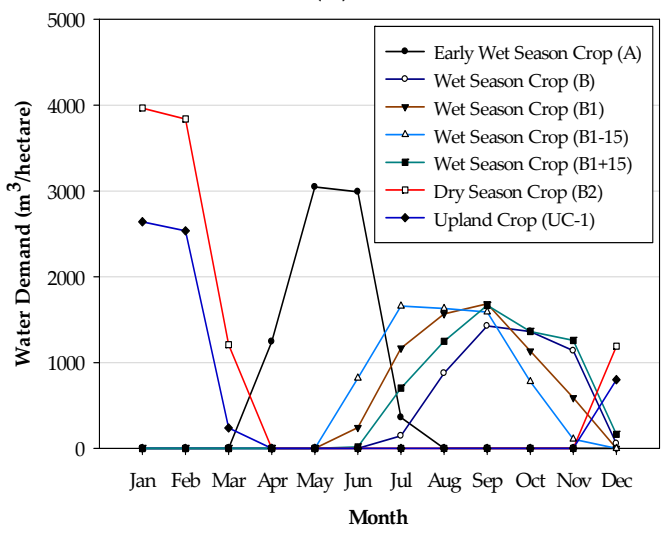

(d)

Figure 6. The unit of irrigation water requirement of each crop type: (a) Baseline, (b) GFDL-CM3 climate model, (c) GISS-E2-R-CC climate model, (d) IPSL-CM5A-MR climate model.

$$
I W R=\left(E T_{0} \times K_{c}+P R-L P-E R\right) / I E
$$

where $I W R$ is irrigation water requirement for diversion unit, $E T_{o}$ is reference evapotranspiration, $K_{c}$ is crop coefficient, $P R$ is percolation rate (in case of paddy), $L P$ is land preparation requirement, $E R$ is effective rainfall, and IE is irrigation efficiency

$$
E T_{0}=P \times\left(0.46 T_{\text {mean }}+8\right)
$$


where $E T_{0}$ is reference crop evapotranspiration ( $\mathrm{mm} /$ day) as an average for a period of one month, $T_{\text {mean }}$ is mean daily temperature $\left({ }^{\circ} \mathrm{C}\right)$, and $P$ is mean daily percentage of annual daytime hours.

$$
E R=0.8 \times R(5 \leq R \leq 80 \mathrm{~mm}), E R \max =64 \mathrm{~mm}
$$

where $E R$ is effective rainfall, $R$ is rainfall, and $E R_{\max }$ is maximum effective rainfall.

Table 4. Crop calendar of each crop varieties in the PRB in the 2008-2009.

\begin{tabular}{cccccc}
\hline No. & Crop Variety & Duration & Start Date & End Date & Area (ha) \\
\hline 1 & Early Wet Season Rice Direct Sowing (A) & 90 days & 1 April & 16 July & 10,181 \\
2 & Wet Season Rice Transplanting (B) & 115 days & 16 July & 11 Nov & 21,029 \\
3 & Wet Season Rice Transplanting (B1) & 140 days & 1 June & 21 Oct & - \\
4 & Wet Season Rice Transplanting (B1-15) & 140 days & 16 May & 6 Oct & 15,980 \\
5 & Wet Season Rice Transplanting (B1 + 15) & 140 days & 16 June & 6 Nov & 11,000 \\
6 & Dry Season Direct Sowing (B2) & 90 days & 1 Dec & 2 Mar & 14,589 \\
7 & Upland Crop (UC-1) & 75 days & 1 Dec & 16 Feb & - \\
\hline
\end{tabular}

Domestic Water Use (DWU) was calculated based on the information of population numbers in each community living along the Pursat river. The population in the PRB was estimated according to the report of the General Population Census of Cambodia (2008) [38]. The future population was projected using the past population growth rate (1999-2016) as the basis. Domestic water use per capita in Cambodia was determined based on the survey data from the Water Supply Performance and Consumption report of the Cambodian's Provincial Water Supply [31]. Annual domestic water use was estimated as 32,850 liter/year/capita.

Industrial Water Use (IWU) was determined according to field survey conducted by JICA [31]. Small and medium-scale existing and planning industrial sites located in the PRB and neighboring catchment have been increasing in recent years. Since 2016, four water supply companies and eight ice factories are being operated in the PRB and neighboring catchment. JICA projects that the industrial water use would be in an increase trend from 2016 to 2025.

The priorities of water demand were set in the following order: urban and rural domestic, industrial, and agricultural uses. The highest priorities were put for water demand inside PRB, while the water demand for neighboring catchments were put in lowest priorities.

For the monthly WEAP model simulation, schematic view interface was established to define the water supply/demand linkage in the basin. 2016 was assigned as the baseline year (Current Account) based on data availability. Each year has 12 time steps from January to December.

\subsection{The SWAT and WEAP Modeling Approach}

\subsubsection{SWAT Modeling Approach}

SWAT is a semi-physically based model intended to simulate the effect of land management practices on the environmental-hydrological system in a watershed over long periods (years to decades). Different physical processes were simulated in SWAT, including water and sediment movement, crop growth, and nutrient cycling [24,39]. During the running process in SWAT, small or large catchments were divided into sub-basin, then subdivided into hydrological response unit (HRUs) with homogeneous land uses, soil types, and terrain slope class.

SWAT examines watershed hydrology in two phases: the land phase and routing phase. The land phase is formed from the watershed land areas which simulate the water transported to the channels, including sediment, nutrients, and pesticides. The routing phase consists of the water performance 
in the waterways, from the tributaries to the outlet of watershed. SWAT simulates hydrology cycle following by water balance equation (Equation (4)).

$$
S W_{t}=S W_{0}+\sum_{i}^{t}\left(R_{\text {day }}-Q_{\text {surf }}-E_{a}-W_{\text {seep }}-G_{w}\right)
$$

where $S W_{t}$ is the final soil water content $\left(\mathrm{mm} \mathrm{H}_{2} \mathrm{O}\right), S W_{0}$ is the initial soil water content on day $i(\mathrm{~mm}$ $\left.\mathrm{H}_{2} \mathrm{O}\right), t$ is the time (days), $R_{\text {day }}$ is the amount of precipitation on day $i\left(\mathrm{~mm} \mathrm{H}_{2} \mathrm{O}\right), Q_{\text {surf }}$ is the amount of surface runoff on day $i\left(\mathrm{~mm} \mathrm{H}_{2} \mathrm{O}\right), E_{a}$ is the amount of evapotranspiration on day $i\left(\mathrm{~mm} \mathrm{H}_{2} \mathrm{O}\right), W_{\text {seep }}$ is the amount of water entering the vadose zone from the soil profile on day $i\left(\mathrm{~mm} \mathrm{H}_{2} \mathrm{O}\right)$, and $Q_{g} w$ is the amount of groundwater exfiltration on day $i\left(\mathrm{~mm} \mathrm{H}_{2} \mathrm{O}\right)$.

The SCS (Soil Conservation Service) curve number method and the Green-Ampt infiltration method were used for the runoff simulation in SWAT. The rational method was modified for estimating the peak runoff rate. The variable storage routing method, or the Muskingum routing method were used for examining water routing in the channel. A shallow aquifer storage area was created to simulate the ground water flow contributed to the total river flow [40], whereby the water was percolated from thee root zone. SWAT used three methods, namely Priestley-Taylor [41], Penman-Monteith [42], and ET-Hargreaves [43] for estimating potential evapotranspiration. SWAT theories and structure are fully explained in the SWAT theoretical documentation [24]. This study uses the SCS curve number and Muskingum routing methods for surface runoff and flow computations while potential evapotranspiration was estimated by the Penman method.

\subsubsection{WEAP Modeling Approach}

The WEAP system is defined as a demand-, priority-, and preference-driven water planning model [25]. It helps water managers to examine both bio-physical factors affecting the river and socio-economic issues influencing the level of domestic, industrial and agriculture demand, environmental flow requirements and reservoir operation management. The principle algorithm of WEAP aims to spatially resolve water balance examined on a monthly basic by balancing water supply and demand at each node and link in the system. Based on scenario analysis, WEAP assists the planner in forecasting demand and supply structure under different scenario assumptions and management options and supports in making resources management policies to fulfill demand and alleviate water allocation issues [44]. The current account year was created in WEAP in which actual water demand, pollution loads, supplies and resources for the system were first taken into account and were then compared to future development.

A demand site's (DS) water demand is defined as the sum of the demands for all the demand site's bottom-level branches (Br) (Equation (5)). A bottom-level branch is one that has no branches below it.

$$
\text { Annual Demand }_{D S}=\sum_{B r}\left(\text { Total Activity Level }_{B r} \times \text { Water Use Rate }_{B r}\right)
$$

The water use rate is the average annual water consumption per unit of activity. In this study, annual water use rate is the sum of annual irrigation water requirement (IWR), industrial water use (IWU), and domestic water use (DWU) expressed in cubic meter $\left(\mathrm{m}^{3}\right)$ per unit of activity.

$$
\text { Water Use Rate } \text { Rr }=\sum_{B r} \text { Unit of Activity }\left(I W R_{B r}+I W U_{B r}+D W U_{B r}\right)
$$

The water demand of each crop type would vary considerably from month to month. The monthly variation is the percentage used to covert the annual water demand into monthly water demand.

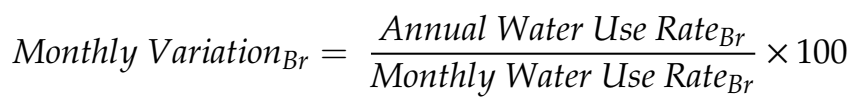


Return flow is remaining flow after consuming by demand site. Consumption is the percentage of inflow consumed (lost from the system). The $95 \%$ of water consumption rate is entered as a fraction of the demand site inflow (supply) based on the manual of WEAP model.

$$
\text { Return Flow }=\text { Inflow } \times(1-\text { Consumption })
$$

The amount supplied to a demand site is the sum of the inflows from its transmission links. The inflow to the demand site from a supply source $(\mathrm{Src})$ is calculated as the outflow from the transmission link connecting them.

$$
\text { Demand Side Inflow } w_{D S}=\sum_{\text {Src }} \text { Trans Link Outflow } \text { Src,DS }_{\text {S }}
$$

\subsection{Climate Change and Water Mangement Scenarios}

Climate change scenarios was developed by multiple GCMs, emission scenarios, time horizons and locations [45]. The most important source of uncertainty in flow and irrigation demand attributed to the different GCMs have been previously identified [17,46,47]. Therefore, the GCM selection of the climate change scenario development procedure is the most important factor. As being used by MRC [45], three GCMs (GFDL-CM3, GISS-E2-R-CC and IPSL-CM5-MR) and RCP: 6.0 (medium emission scenarios) were considered to assess the general impacts of climate change. The time horizon 2060s (medium-term future 2051-2070) was considered, as this time horizon is being used by MRC in other forecast perspectives.

Three climate model were developed by three institutions, namely the Institute Pierre-Simon Laplace (IPSL) [48], NASA Goddard Institute for Space Studies (GISS) [49], and Geophysical Fluid Dynamics Laboratory (GFDL) [50]. Basically, GISS-E2-R-CC projects a drier future on average across all locations and seasons (i.e., less rain in most of the study basin, but there are some local departures from this pattern [45]. IPSL-CM5A-MR represents the medium scenario, since it projects wetter wet seasons and drier dry season (i.e., increased seasonal variability). GFDL-CM3 is the upper bound of projected future impacts (i.e., wetter overall).

A dataset of downscaled global climate change scenario (IPCC 5th Assessment Report) were acquired from the MRC Climate Change and Adaptation Initiative (CCAI). The SWAT model dataset consists of monthly change factors for precipitation, temperature, solar radiation, and relative humidity. SimCLIM software was used by MRC for the climate downscaling. The pattern scaling plus bilinear interpolation algorithm was used in SimCLIM for downscaling the GCM outputs. As the change factor approach represents the simplest and most practical way to produce scenarios based on multiple GCMs, emission scenarios, sensitivities, time horizons and locations, the change factors were used by MRC CCAI for quantifying the projected alterations to the climate [45].

Water management scenarios include: (1) Reference scenario $\left(\mathrm{S}_{0}\right)$ : Existing and planned irrigation scheme and command area, including the irrigated area in the neighboring catchment, and current status of population and industrial site. (2) Annual increase in water demand scenario $\left(\mathrm{S}_{\mathrm{I}}\right)$ : Planting area annually increase by $18 \%$ in the neighboring catchment and by $8 \%$ in an irrigated area extension project from 2016 to 2025, future population projected based on historical data (both urban and rural population) with a 1.4\% growth rate, and industrial water demands increase from 2016 to 2025. (3) Additional reservoir storage scenario ( $\mathrm{S}_{\text {III }}$ ): As in $\mathrm{S}_{\text {II }}$ but adding new reservoir (Dam No.1) from 2021 with total capacity of $1014 \mathrm{MCM}$. (4) Environmental flow scenario $\left(\mathrm{S}_{\mathrm{E}}\right)$ : As in $\mathrm{S}_{\mathrm{I}}$, without considering reservoir (Dam No. 1), but maintaining 30\% of annual streamflow for biodiversity conservation in ecosystem. (5) Environmental flow scenario $\left(\mathrm{S}_{\mathrm{IE}}\right)$ : As in $\mathrm{S}_{\mathrm{E}}$, but considering reservoir (Dam No. 1). The water supply-demand relations were examined using a few different indicators including water demand, unmet demand under the combinations of water management and climate change scenarios (Tables 5 and 6). Water unmet demand refers to the amount of water that are not fulfilled demand requirements. Water shortages occur when demands are not fully met at a particular location or the 
whole region. The different alternative analysis covers a wide range of potential future water stresses in the PRB under three climate model projections. 
Table 5. Water management scenario descriptions.

\begin{tabular}{|c|c|c|c|c|}
\hline Scenarios & Crop Irrigation Demand & Domestic and Industrial Water Demand & Additional Reservoir Storage & $\begin{array}{l}\text { Environment Flow } \\
\text { Requirement }\end{array}$ \\
\hline Reference $\left(\mathrm{S}_{0}\right)$ & $\begin{array}{l}\text { Existing and planned irrigation } \\
\text { scheme and command area, } \\
\text { including the irrigated area in } \\
\text { the neighboring catchment. }\end{array}$ & $\begin{array}{c}\text { Current status of population number and } \\
\text { industrial site. }\end{array}$ & No & No \\
\hline $\begin{array}{l}\text { Annual Increase in Water } \\
\text { Demand }\left(\mathrm{S}_{\mathrm{I}}\right)\end{array}$ & $\begin{array}{l}\text { Planting area annually increase } \\
\text { by } 18 \% \text { in the neighboring } \\
\text { catchment and by } 8 \% \text { in an } \\
\text { irrigated area extension project } \\
\text { from } 2016 \text { to } 2025 \text {. }\end{array}$ & $\begin{array}{l}\text { Future population projected based on } \\
\text { historical data (both urban and rural } \\
\text { population) with a 1.4\% growth rate, and } \\
\text { industrial water demands increase from } \\
2016 \text { to } 2025 \text {. }\end{array}$ & No & No \\
\hline $\begin{array}{l}\text { Additional Reservoir } \\
\text { Storage }\left(\mathrm{S}_{\mathrm{II}}\right)\end{array}$ & As $S_{I}$ & 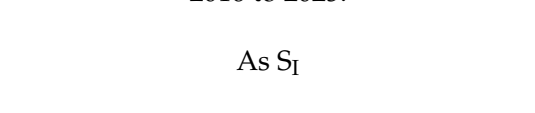 & $\begin{array}{l}\text { Adding Reservoir Dam No.1 } \\
\text { from } 2021 \text { with capacity of } 1014 \\
\text { MCM. }\end{array}$ & No \\
\hline Environmental Flow $\left(\mathrm{S}_{\mathrm{E}}\right)$ & As $S_{I}$ & As $S_{I}$ & No & $\begin{array}{c}\text { Maintaining } 30 \% \text { of annual } \\
\text { streamflow for sustaining } \\
\text { biodiversity in ecosystem. }\end{array}$ \\
\hline Environmental Flow $\left(\mathrm{S}_{\mathrm{IE}}\right)$ & As $S_{I}$ & As $S_{I}$ & As $S_{I I}$ & As $S_{E}$ \\
\hline
\end{tabular}

Table 6. The descriptions of Climate Change Scenario.

\begin{tabular}{|c|c|c|c|c|}
\hline Climate Scenarios & $\begin{array}{l}\text { Projected Future Streamflow } \\
\text { and Irrigation Water Demand }\end{array}$ & $\begin{array}{l}\text { Crop Irrigation, Domestic and } \\
\text { Industrial Water Demand }\end{array}$ & Additional Reservoir Storage & $\begin{array}{c}\text { Environment Flow } \\
\text { Requirement }\end{array}$ \\
\hline Scenario: $\mathrm{S}_{\mathrm{C}}$ & $\begin{array}{c}\text { GFDL-CM3: Wet } \\
\text { GISS-E2-R-CC: Dry } \\
\text { IPSL-CM5A-MR: Medium }\end{array}$ & As $S_{I}$ & No & No \\
\hline Scenario: SIC $_{\text {IC }}$ & $\begin{array}{c}\text { GFDL-CM3: Wet } \\
\text { GISS-E2-R-CC: Dry } \\
\text { IPSL-CM5A-MR: Medium }\end{array}$ & As $S_{I}$ & As $S_{I I}$ & No \\
\hline Scenario: $\mathrm{S}_{\text {IIC }}$ & $\begin{array}{c}\text { GFDL-CM3: Wet } \\
\text { GISS-E2-R-CC: Dry } \\
\text { ISPL-CM5A-MR: Medium }\end{array}$ & As $S_{I}$ & No & As $S_{\mathrm{IE}}$ \\
\hline Scenario: $\mathrm{S}_{\text {IIIC }}$ & $\begin{array}{c}\text { GFDL-CM3: Wet } \\
\text { GISS-E2-R-CC: Dry } \\
\text { ISPL-CM5A-MR: Medium }\end{array}$ & As $S_{I}$ & As $S_{I I}$ & As $S_{\mathrm{IE}}$ \\
\hline
\end{tabular}




\subsection{Environmental Flow Requirement}

Besides the water for food production and other human needs, the amount of water needed for the environment flow requirement (EFR) must be also quantified for sustaining freshwater ecosystem [51]. The process for quantifying recommended flows is to achieve an agreement among all the aspects on a flow regime modification that will be inadequate to meet the requirement of all species, components and processes in the river during different time periods [52]. As recommended by [53], 24-27\% of annual streamflow released from a hydropower dam needs to be maintained as the required environmental flow for optimal energy production and sustainable ecosystem. Thirty percent of the annual stream flow was assumed to be the minimum E-flows demand for sustaining the stream's ecosystems in tributary basin of Tonle Sap lake [54]. Therefore, thirty percent of annual streamflow would be maintained as minimum flow at the outlet of the PRB.

\subsection{Safety Level of the Water Balance}

Water balance computation defines the safety level for all proposed irrigation schemes. The safety level is defined by the formula:

$$
\text { Safety Level }=\frac{x+1}{n}
$$

where $x$ is the number of occurrences of 20-day successive deficits (irrigation failure), and $n$ is the total number of simulated years $(n=20)$. Each irrigation scheme is considered successful if the safety level is less than $5 / 20$. The criterion is designed to permit shortage less than $25 \%$ of water shortage years.

\section{Results}

\subsection{Impacts of Climate Change on Flow regime and Hydrological Extreme}

The future flow changes were analyzed through the change in meteorological data as projected by three GCMs under RCP 6.0. Modeling simulations indicated that the impacts magnitude of climate change on river flow varied considerably depend on seasonal climate. The projected hydrographs and percentage changes in the monthly flow illustrated a clear trend in changes (Figure 7a,b). Dry season flow will decrease for GISS-E2-R-CC and IPSL-CM5A-MR, with the exceptions for GFDL-CM3 (Figure 7b). The significant rising flows was 22\% in March for GFDL-CM3. The highest magnitude flow reduction was $-43 \%$ in January for GISS-E2-R-CC and -36\% in April for IPSL-CM5A-MR. Similarly, wet season flow will reduce for all GCMs. The highest magnitude of flow reduction was $-47 \%$ for GISS-E2-R in July, and $-27 \%$ and $-36 \%$ in August for GFDL-CM3 and IPSL-CM5A, respectively (Figure 7b).

The seasonal flows will decline during both wet and dry season for most GCMs, in particular, for GISS-E2-R-CC while that in dry season were projected to increase only for GFDL-CM3 (Figure 7c). The annual flows are projected to decline with the percentage changes of $14 \%, 38 \%$, and $15 \%$ for GFDL-CM3, GISS-E2-R-CC, and IPSL-CM5A-MR, respectively and the most significant of annual flow reduction was projected by the GISS-E2-R-CC model.

Climate change has the potential to noticeably alter river flow regimes, contributing to the changes in extreme events, i.e., floods and droughts, particularly $Q_{5}$ (high flows exceeded only $5 \%$ of the time) and $\mathrm{Q}_{95}$ (low flows exceeding 95\% of the time) (Table 7). The $\mathrm{Q}_{5}$ values showed a decreasing trend for all GCMs, especially for GISS-E2-R-CC (Figure 7d). The $\mathrm{Q}_{5}$ river flow shows a decrease of $4.5 \%, 33.2 \%$, and $7.9 \%$ for GFDL-CM3, GISS-E2-R-CC, and IPSL-CM5A-MR, respectively. The $\mathrm{Q}_{95}$ values decreased under all GCMs, mostly for IPSL-CM5A-MR (Table 7). The $\mathrm{Q}_{95}$ shows a reduction of 79\%, $88.2 \%$, and 96.8 for GFDL-CM3, GISS-E2-R-CC, and IPSL-CM5A-MR, respectively. 


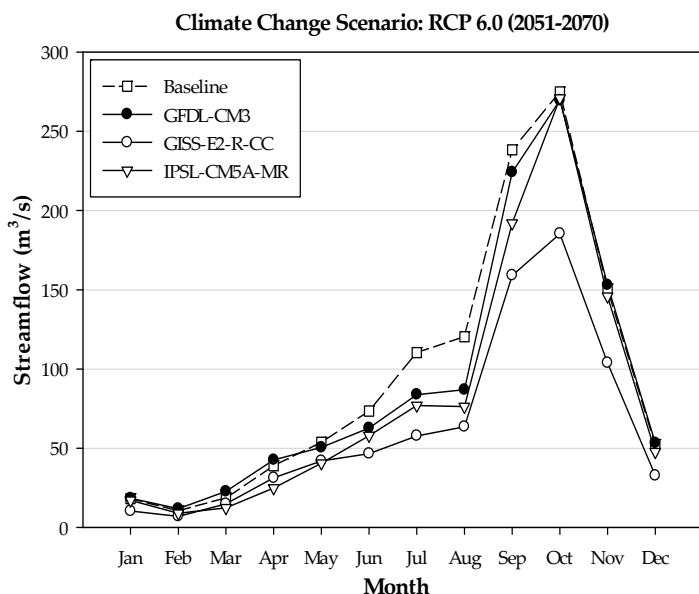

(a)

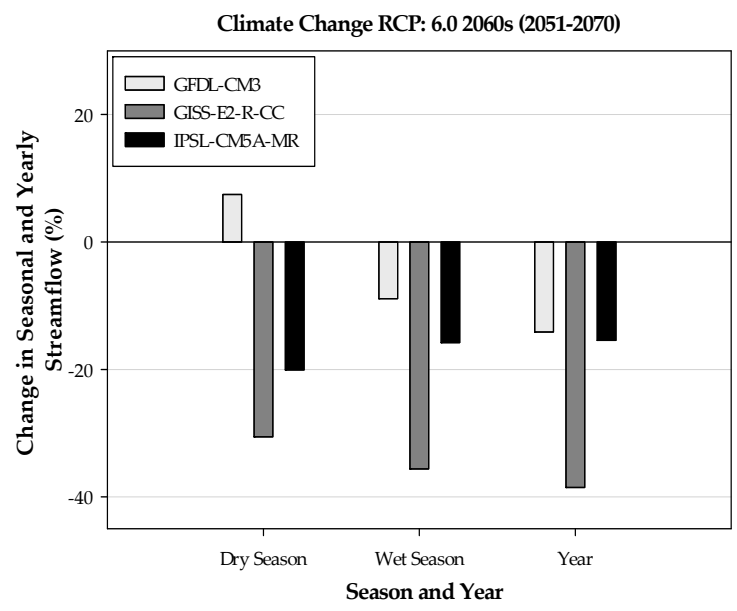

(c)

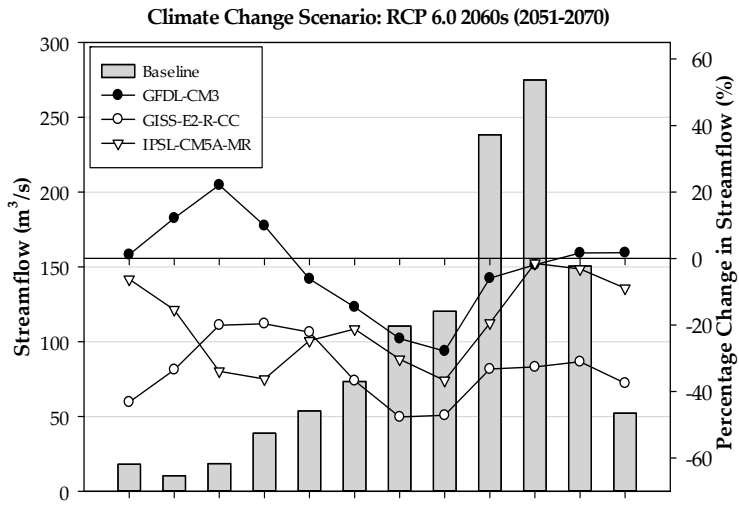

Jan Feb Mar Apr May Jun Jul Aug Sep Oct Nov Dec Month

(b)

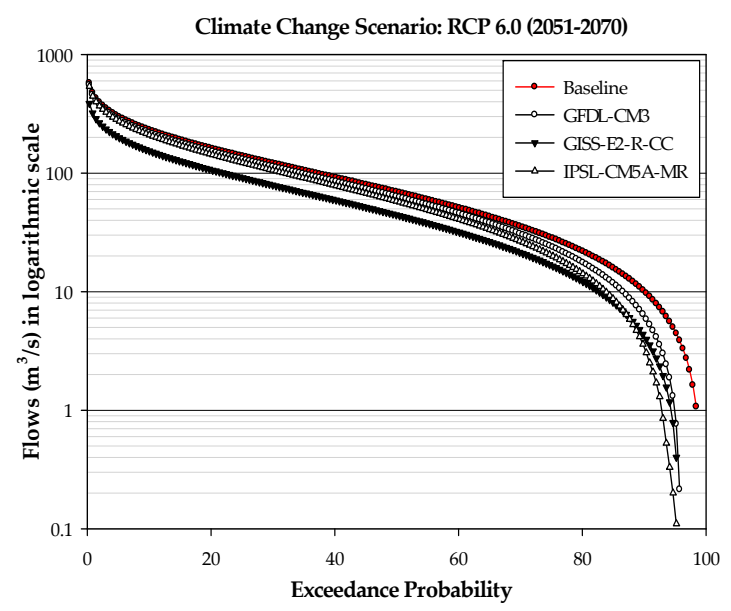

(d)

Figure 7. (a) The comparison of baseline and future streamflow, (b) The change in future streamflow, (c) The change in seasonal and annual streamflow, (d) The exceedance probability of flow.

Table 7. Percentage changes in $\mathrm{Q}_{5}$ and $\mathrm{Q}_{95}$ during the future time periods.

\begin{tabular}{|c|c|c|c|c|c|c|c|}
\hline \multirow[b]{2}{*}{ Flow } & \multirow{2}{*}{$\begin{array}{l}\text { Baseline } \\
\text { Stream } \\
\text { Flow * }\end{array}$} & \multicolumn{2}{|c|}{ GFDL-CM3 } & \multicolumn{2}{|c|}{ GISS-E2-R-CC } & \multicolumn{2}{|c|}{ IPSL-CM5A-MR } \\
\hline & & $\begin{array}{l}\text { Stream } \\
\text { Flow * }\end{array}$ & $\begin{array}{l}\text { Percentage } \\
\text { Change }(\%)\end{array}$ & $\begin{array}{l}\text { Stream } \\
\text { Flow * }\end{array}$ & $\begin{array}{l}\text { Percentage } \\
\text { Change }(\%)\end{array}$ & $\begin{array}{l}\text { Stream } \\
\text { Flow * }\end{array}$ & $\begin{array}{l}\text { Percentage } \\
\text { Change (\%) }\end{array}$ \\
\hline $\mathrm{Q}_{5}$ & 300.7 & 287.2 & -4.5 & 200.9 & -33.2 & 276.9 & -7.9 \\
\hline $\mathrm{Q}_{95}$ & 4.6 & 0.9 & -79 & 0.5 & -88.2 & 0.1 & -96.8 \\
\hline
\end{tabular}

\subsection{Water Supply and Demand under E-Flow Maitenance and Management Options}

The irrigated areas were 39,387 ha in 2016 and projected to be 86,858 ha in 2025 . The irrigation water demand (IWD) in $\mathrm{S}_{0}, \mathrm{~S}_{\mathrm{I}}$, and $\mathrm{S}_{\mathrm{II}}$ significantly increase from 2018 to 2019 since Kbal Hong and Damnak Ampil irrigation schemes were included in 2018 and 2019, respectively (Figure 8a). The irrigation demand (IWD) was the highest one, followed by the domestic demand (DWU) and the industrial demand (IDW) (Figure 8b). $\mathrm{S}_{0}$ found the highest IDW by $61.4 \mathrm{MCM}$ in January and 52.4 MCM in September during dry and wet season, respectively. No significance of monthly variation of IDW and DWU was found (Figure 8c). In $\mathrm{S}_{\mathrm{I}}$, the percentage increase of IDW, DWU, and IWD were from $8 \%, 1.4 \%$, and $4.1 \%$ in 2017 to $100 \%, 13.5 \%$, and $37.4 \%$ in 2025, respectively (Figure $8 \mathrm{~d}$ ). 


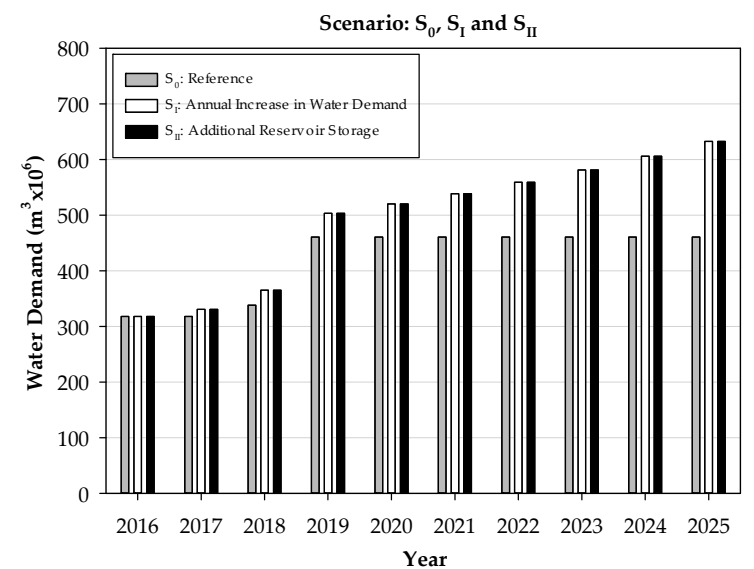

(a)

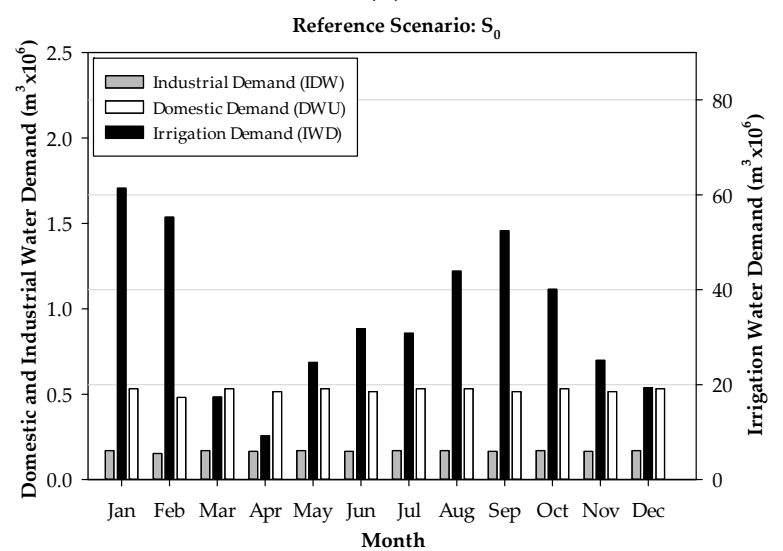

(c)

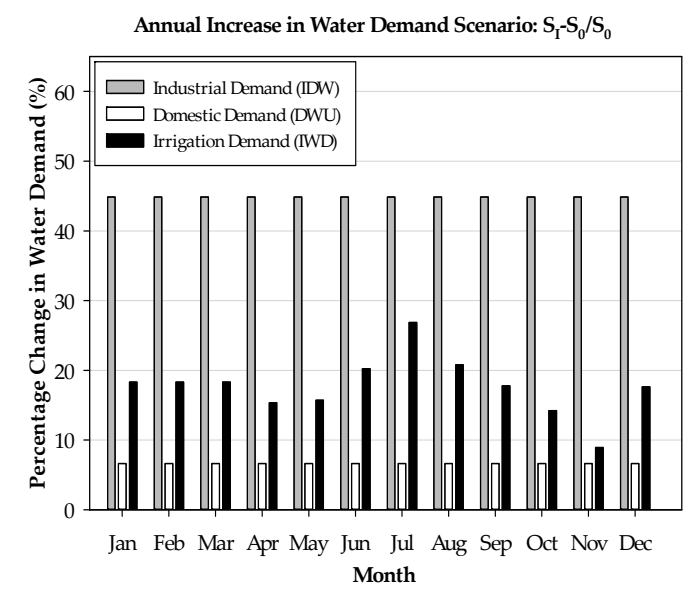

(e)

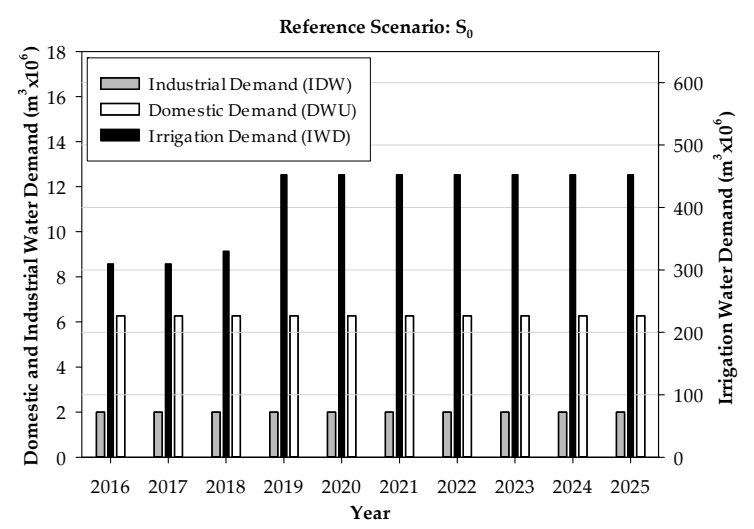

(b)

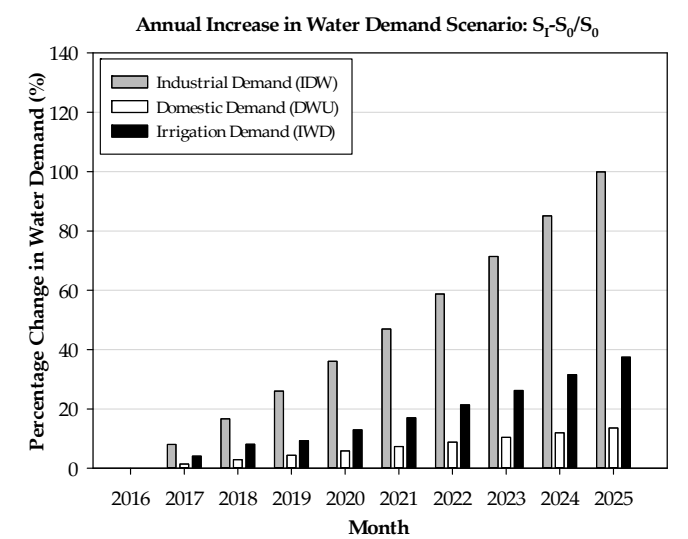

(d)

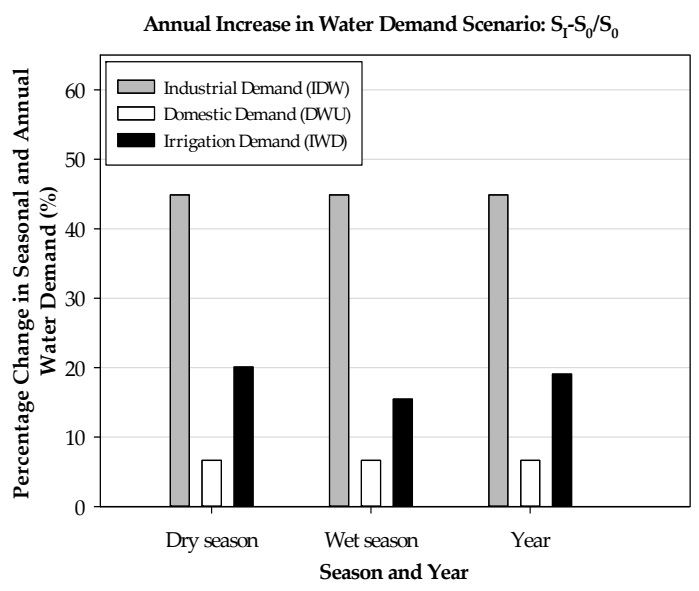

(f)

Figure 8. (a) The comparison of water demand between different scenario, (b) The comparison of annual water demand by each purpose in So, (c) The comparison of monthly water demand by each purpose, (d) The percentage change in annual water demand in $\mathrm{S}_{\mathrm{I}}$, (e) The percentage change in monthly water demand in $\mathrm{S}_{\mathrm{I}},(\mathrm{f})$ The percentage change in seasonal and annual water demand in $\mathrm{S}_{\mathrm{I}}$.

Furthermore, the highest percentage of monthly IWD increase was $26.9 \%$ in July while IDW and DWU show non-signification variation of monthly increase (Figure 8e). The percentage of seasonal and annual increase of IWD was 20\%, 15.5\%, and 19\% in dry, wet season and annual, respectively (Figure 8f). 
The unmet demand (UD) will gradually increase from 0.6 MCM in 2019 to 40.8 MCM in 2025 under $\mathrm{S}_{\mathrm{I}}$. With reservoir, the significant UD will occur only from 2020 to 2021, and there will be no unmet demand from 2022 (Figure 9a). With E-flow, UD increased from 11.2 MCM in 2016 to $63.5 \mathrm{MCM}$ in 2025 (Figure 9b). The total UD for industrial (IDUn), domestic (DWUn) and irrigation (IWUn) were highest in February under $\mathrm{S}_{\mathrm{E}}$, followed by $\mathrm{S}_{\mathrm{I}}, \mathrm{S}_{\mathrm{II}}$, and $\mathrm{S}_{\mathrm{IE}}$ (Figure 9c). With the reservoir in $\mathrm{S}_{\mathrm{II}}$, the significant UD decrease was $-87 \%$ in February (Figure $9 d$ ). Under $S_{I}$, the IWUn, DWUn and IDUn were 4.6 MCM, 860.4 CM, and $1262 \mathrm{CM}$, respectively, in February (Table 8). With E-flows in $\mathrm{S}_{\mathrm{E}}$, the IWUn, DWUn, and IDUn were 14.6 MCM, 860.4 CM, and $1262 \mathrm{CM}$, respectively, in February (Table 9). With reservoir in $\mathrm{S}_{\mathrm{II}}$ and $\mathrm{S}_{\mathrm{IE}}$, the IWUn, DWUn, and IDUn show a significant decrease during dry season, mainly in February (Tables 8 and 9).

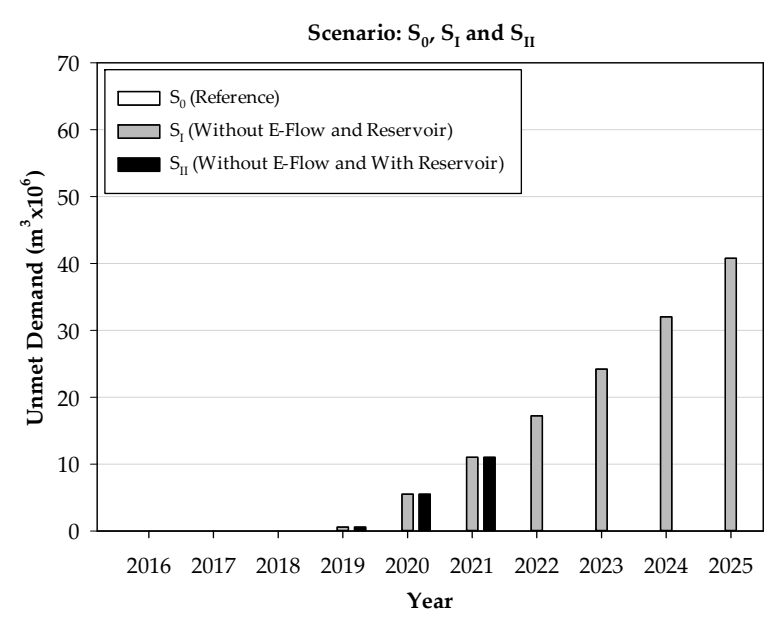

(a)

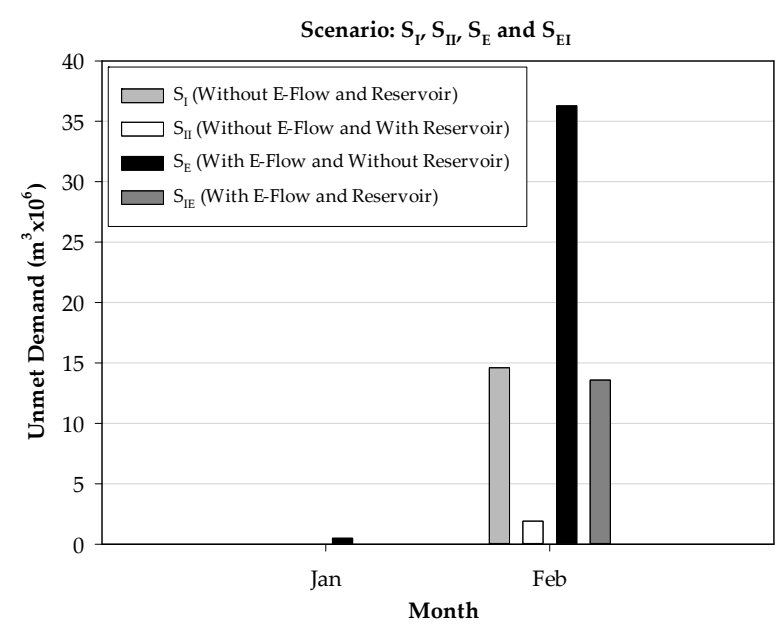

(c)

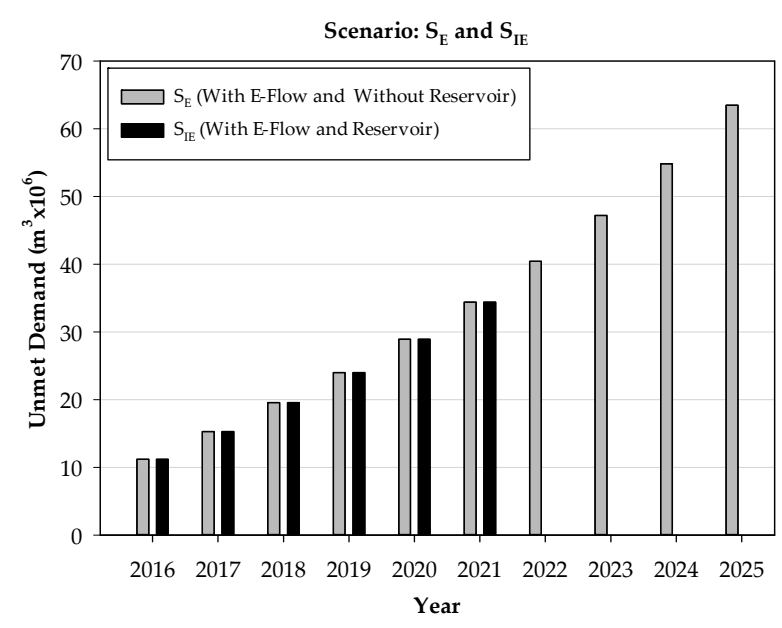

(b)

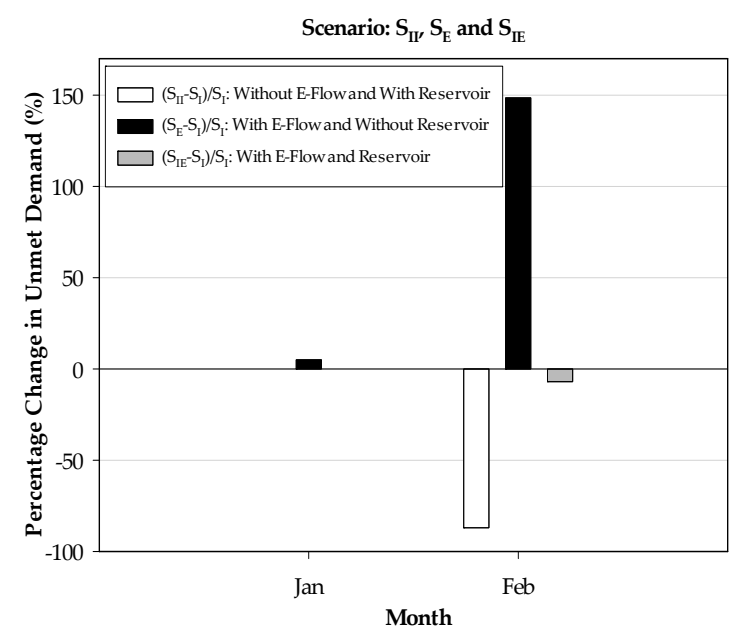

(d)

Figure 9. (a) The comparison of annual unmet demand between $S_{0}, S_{I}$ and $S_{I I}$, (b) The comparison of annual unmet demand between $\mathrm{S}_{\mathrm{E}}$ and $\mathrm{S}_{\mathrm{IE}}$, (c) The comparison of monthly unmet demand between $\mathrm{S}_{\mathrm{I}}$, $\mathrm{S}_{\mathrm{II}}, \mathrm{S}_{\mathrm{E}}$ and $\mathrm{S}_{\mathrm{IE}}$, (d) The percentage change of monthly unmet demand in $\mathrm{S}_{\mathrm{II}}, \mathrm{S}_{\mathrm{E}}$ and $\mathrm{S}_{\mathrm{IE}}$. 
Table 8. The change in monthly unmet demand by each purpose in $S_{I}$ and $S_{I I}$.

\begin{tabular}{|c|c|c|c|c|c|c|}
\hline \multirow{3}{*}{ Unmet Demand } & \multicolumn{2}{|c|}{ SII $_{\mathrm{I}}$ Without Reservoir } & \multicolumn{4}{|c|}{ SII $_{\text {II }}$ With Reservoir } \\
\hline & \multirow{2}{*}{ Jan } & \multirow{2}{*}{ Feb } & \multirow{2}{*}{ Jan } & \multirow{2}{*}{ Feb } & \multicolumn{2}{|c|}{ Percentage Change (\%) } \\
\hline & & & & & Jan & Feb \\
\hline IWUn & 0 & $14.6 * *$ & 0 & $2 * *$ & 0 & -86 \\
\hline DWUn & 0 & $860.4 *$ & 0 & 0 & 0 & -100 \\
\hline IDUn & 0 & 1262 * & 0 & 0 & 0 & -100 \\
\hline
\end{tabular}

Table 9. The change in monthly unmet demand by each purpose in $\mathrm{S}_{\mathrm{E}}$ and $\mathrm{S}_{\mathrm{IE}}$.

\begin{tabular}{|c|c|c|c|c|c|c|}
\hline \multirow{3}{*}{ Unmet Demand } & \multicolumn{2}{|c|}{$\mathrm{S}_{\mathrm{E}}$ : Without Reservoir } & \multicolumn{4}{|c|}{ S IE $_{\text {IE }}$ With Reservoir } \\
\hline & \multirow{2}{*}{ Jan } & \multirow{2}{*}{ Feb } & \multirow{2}{*}{ Jan } & \multirow{2}{*}{ Feb } & \multicolumn{2}{|c|}{ Percentage Change (\%) } \\
\hline & & & & & Jan & Feb \\
\hline IWUn & 1 & $36.28 * *$ & 0 & $13.6^{* *}$ & -100 & -62.5 \\
\hline DWUn & 0 & $40,402 *$ & 0 & $1953.9 *$ & - & -95 \\
\hline IDUn & 0 & $64,915 *$ & 0 & $1020.7 *$ & - & -98.4 \\
\hline
\end{tabular}

\subsection{The Effects of Climate Change on Water Demand and Supply under E-Flows maintenance and Mangement Options}

The potential effects of climate change refer to the alteration of future climate data (i.e., temperature and precipitation) which result in the change in hydrology (i.e., water supply) and irrigation water requirement (i.e., water demand). Figure 10a illustrated comparatively significant difference of projected IWD by the future period (2060s: 2051-2070), compared to the present (2020s: 2016-2025). The overall monthly increase was substantial greater than $20 \%$ for all GCMs under RCP 6.0. These results were in agreement with studies of multimodal projections of IWD under climate change [14]. The monthly IWD increases in the dry season ranging from $22 \%$ to $36 \%$ for all climate change scenarios (Figure 10a). The most significant of dry season IWD increases was 36\% for IPSL-CM5A-MR. Similarly, it will increase during wet season, ranging from $30 \%$ to $41 \%$ for all climate change scenarios and the highest magnitude of rising IDW was 35\% for GFDL-CM3 in April and 41\% in July for GISS-E2-R-CC and IPSL-CM5A-MR, respectively. The relative change between the projected seasonal IWD and the baseline seasonal IWD illustrated that the seasonal IWD will increase during both wet and dry seasons for all GCMs, in particular, for GISS-E2-R-CC (Figure 10b).

The water supply delivery noticeably decreased from 2051 to 2070 for all climate models. The future water supply requirements and unmet demand were projected to largely increase under GISS-E2-R-CC as well as under IPSL-CM5A-MR. Without reservoir in $\mathrm{S}_{\mathrm{C}}$ and $\mathrm{S}_{\text {IIC }}$, the UD in dry season will increase for all climate change scenario (Figure 10c) and percentage changes were large, changing to $413 \%$ and $143 \%$ under $\mathrm{S}_{\mathrm{C}}$ and $\mathrm{S}_{\text {IIC }}$ for GISS-E2-R-CC, respectively. However, with reservoir in $\mathrm{S}_{\text {IC }}$ and $\mathrm{S}_{\text {IIIC, }}$ the UD will decrease for all climate change scenario. The overall relative change of UD reduction was $-100 \%$ in $S_{\text {IC }}$ and $S_{\text {IIIC }}$, respectively in dry season under all GCMs. Without reservoir, the highest increase in IDUn was 324\% and 197\% (Figure 10d), in DWUn was 236\% and 314\% (Figure 10e), and in IWUn was $411 \%$ and $143 \%$ (Figure 10f) under $\mathrm{S}_{\mathrm{C}}$ and $\mathrm{S}_{\text {IIC }}$, respectively for GISS-E2-R-CC. The significant decrease in IDUn and DWUn was $-35 \%$ and $-45 \%$, respectively under $\mathrm{S}_{C}$ for GFDL-CM3 (Figure 10d, 10e). With reservoirs in $\mathrm{S}_{\mathrm{IC}}$ and $\mathrm{S}_{\mathrm{IIIC}}$, no sign of IDUn, DWUn, and IWUn occurred for all GCMs (Figure 10d-f). 


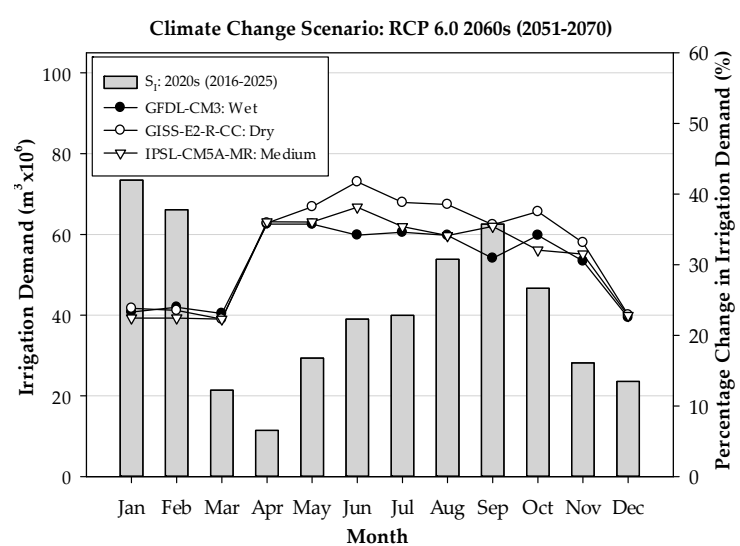

(a)

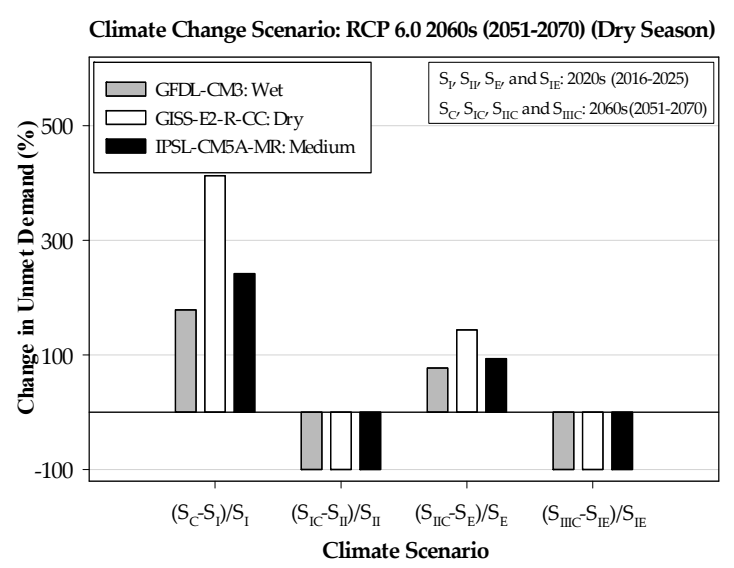

(c)

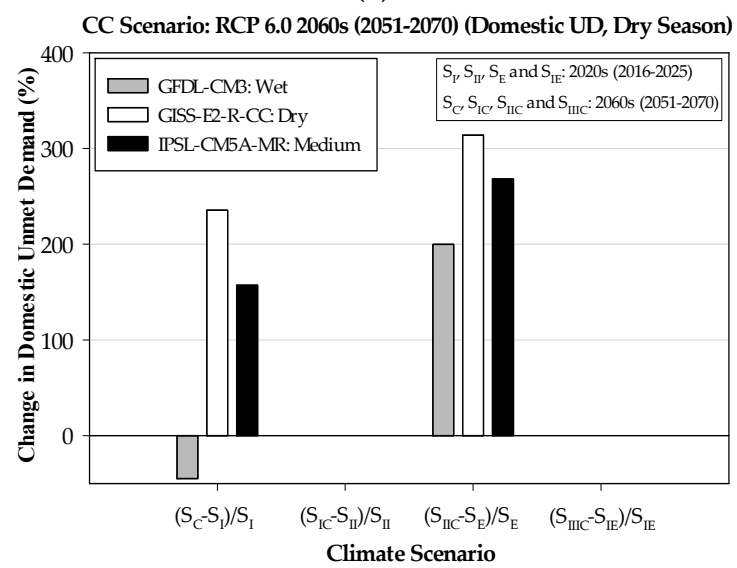

(e)

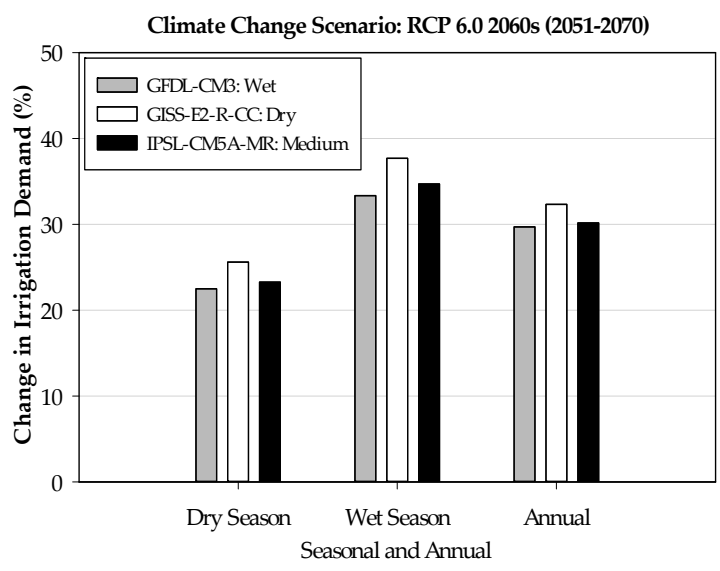

(b)

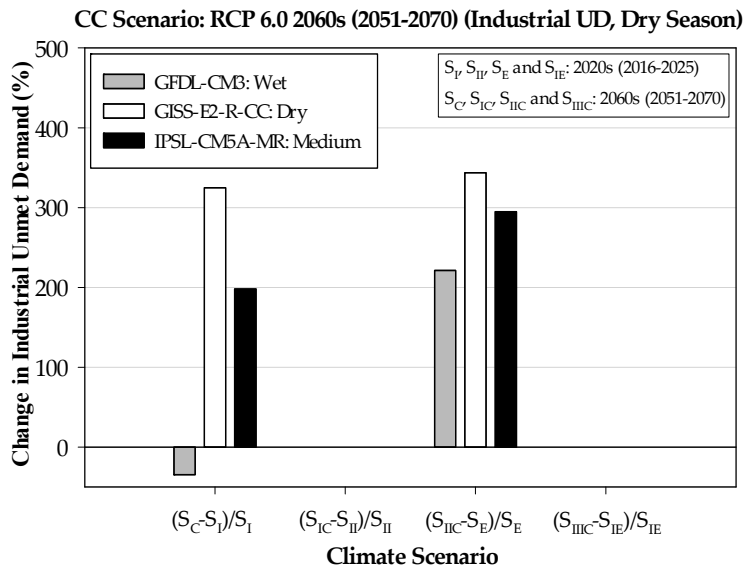

(d)

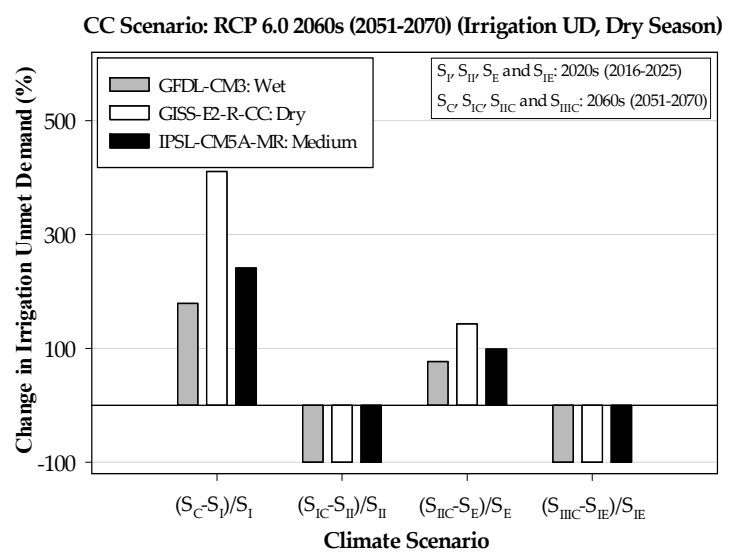

(f)

Figure 10. (a) The future change in IWD, (b) The percentage change in seasonal and annual IWD, (c) The percentage change in future unmet demand, (d) The percentage change in future IDUn, (e) The percentage change in future DWUn, (f) The percentage change in future IWUn.

\subsection{Safety Level of Water Balance}

The highest priority in the water allocation system was DWU followed by IDW and IWR inside the PRB. The irrigation water deficit will happen if the net available flow was less than IWR. All purposes of water use were satisfied, and no water deficit occurs when reservoirs were considered. The water balance safety level was computed by using Equation (9) as shown in Table 10. The results indicated that between 2051 and 2070, more than 20 days of successive water deficits will occur in Charek, 
Damnak Ampil, and Damnak Chheukrom and neighboring catchment namely Svay Dounkeo and Boeurng Khnar during dry season, as indicated by a safety level of greater than 5/20. The deficits are likely to occur in February, May and September of the year which has longer dry season. It will start occurring between 2043 and 2060 in SIE, 2043 and 2069 in SIIIC (GFDL-CM3), 2040 and 2053 in $\mathrm{S}_{\text {IIIC }}$ (GISS-E2-R-CC), and 2041 and 2056 in SIIIC (IPSL-CM5A-MR). Startup years of deficit refer to the year when available water will be less than water demand. When the startup year of deficit has been identified, irrigated land expansion should also be limited (Table 11).

Table 10. The computation of water balance safety level in each irrigation scheme.

\begin{tabular}{|c|c|c|c|c|c|}
\hline \multirow{2}{*}{ Irrigation Scheme } & \multicolumn{4}{|c|}{$\begin{array}{l}\text { Water Balance Safety Level }(n=20: 2051-2070) \text { If Irrigated Area } \\
\text { Increase from } 2025 \text { to } 2070 \text { (With E-Flow and Reservoir) }\end{array}$} & \multirow{2}{*}{$\begin{array}{c}\text { Water Balance } \\
\text { Safety Level } \\
\text { Criteria }\end{array}$} \\
\hline & $\begin{array}{l}\text { Irrigated Area } \\
\text { in } 2025 \text { (ha) }\end{array}$ & GFDL-CM3 & GISS-E2-R-CC & IPSL-CM5A-MR & \\
\hline Svay Dounkeo RS (B2) & 3614 & $1 *$ & $1 *$ & $1 *$ & \\
\hline Boeung Khnar RS (B2) & 6714 & $1 *$ & $1 *$ & $1 *$ & \\
\hline Charek (B2) & 6996 & $1 *$ & $1 *$ & $1 *$ & \\
\hline Charek (A) & 670 & $14 / 20 *$ & $19 / 20 *$ & $16 / 20 *$ & \\
\hline Charek (B1) & 11,074 & $1 *$ & $1 *$ & $1 *$ & \\
\hline Damnak Ampil (B2) & 3500 & $1 *$ & $1 *$ & $1 *$ & \\
\hline D. Ampil Ext. (A) & 4917 & $1 *$ & $1 *$ & $1 *$ & $\leq 5 / 20(1 / 4)$ \\
\hline D. Ampil Ext. (B1) & 14,992 & $1 *$ & $1 *$ & $1 *$ & \\
\hline D. Chheukrom (A) & 6000 & $13 / 20 *$ & $1 *$ & $16 / 20 *$ & \\
\hline D. Chheukrom (B) & 16,100 & $15 / 20 *$ & $1 *$ & $17 / 20 *$ & \\
\hline Kbal Hong R (B1) & 2000 & $3 / 20$ & $9 / 20 *$ & $5 / 20$ & \\
\hline O Rorkar (B1) & 4700 & $13 / 20 *$ & $19 / 20 *$ & $15 / 20 *$ & \\
\hline All Others & 5580 & $1 / 20$ & $1 / 20$ & $1 / 20$ & \\
\hline
\end{tabular}

* Water deficit occurrences.

Table 11. The limited irrigated area for safety water balance and startup year of deficits.

\begin{tabular}{|c|c|c|c|c|c|c|c|c|}
\hline \multirow{3}{*}{ Irrigation Scheme } & \multicolumn{8}{|c|}{ If Irrigated Area Increase from 2025 to 2070 (With E-Flow and Reservoir) } \\
\hline & \multicolumn{4}{|c|}{ Limited Irrigated Area (ha) } & \multicolumn{4}{|c|}{ Startup Year of Deficits } \\
\hline & $\begin{array}{c}\text { No } \\
\text { Climate } \\
\text { Change }\end{array}$ & $\begin{array}{l}\text { GFDL } \\
\text {-CM3 }\end{array}$ & $\begin{array}{l}\text { GISS-E2 } \\
\text {-R-CC }\end{array}$ & $\begin{array}{c}\text { IPSL } \\
\text {-CM5A } \\
\text {-MR }\end{array}$ & $\begin{array}{c}\text { No } \\
\text { Climate } \\
\text { Change }\end{array}$ & $\begin{array}{l}\text { GFDL } \\
\text {-CM3 }\end{array}$ & $\begin{array}{l}\text { GISS-E2 } \\
\text {-R-CC }\end{array}$ & $\begin{array}{c}\text { IPSL } \\
\text {-CM5A } \\
\text {-MR }\end{array}$ \\
\hline Svay Dounkeo (B2) & 60,268 & 60,268 & 36,681 & 43,284 & 2043 & 2043 & 2040 & 2041 \\
\hline Boeung Khnar (B2) & $6714 *$ & $6714 *$ & $6714 *$ & $6714 *$ & 2043 & 2043 & 2040 & 2042 \\
\hline Charek (B2) & 27,958 & 25,887 & 20,550 & 23,970 & 2044 & 2043 & 2040 & 2042 \\
\hline Charek (A) & 8869 & 8211 & 5589 & 7040 & 2059 & 2058 & 2053 & 2056 \\
\hline Charek (B1) & 11,439 & 75,843 & 51,618 & 70,225 & 2056 & 2051 & 2046 & 2050 \\
\hline Damnak Ampil (B2) & $3500 *$ & $3500 *$ & $3500 *$ & $3500 *$ & 2044 & 2043 & 2040 & 2042 \\
\hline D. Ampil Ext. (A) & 24,754 & 36,371 & 15,599 & 16,847 & 2047 & 2046 & 2041 & 2042 \\
\hline D. Ampil Ext. (B1) & 75,470 & 59,910 & 44,036 & 47,559 & 2047 & 2044 & 2040 & 2041 \\
\hline D. Chheukrom (A) & $6000 *$ & $6000 *$ & $6000 *$ & $6000 *$ & 2060 & 2059 & 2052 & 2056 \\
\hline D. Chheukrom (B) & 16,100 * & 16,100 * & $16,100 *$ & 16,100 * & 2062 & 2057 & 2051 & 2055 \\
\hline Kbal Hong R (B1) & $2000^{*}$ & $2000 *$ & $2000 *$ & $2000 *$ & 2070 & 2069 & 2063 & 2067 \\
\hline O Rorkar (B1) & $4700^{*}$ & $4700 *$ & $4700 *$ & $4700 *$ & 2063 & 2058 & 2052 & 2057 \\
\hline
\end{tabular}

* No significant increase of irrigate area.

\section{Discussion}

\subsection{Impacts of Climate Change on Flow Regime and Hydrological Extreme}

The consequence assessment of possible effects of climate change on river flow in the PRB was conducted by comparing climate change scenarios to the baseline scenario. An ensemble of three GCMs under RCP 6.0 during 2060s were developed to analyze extensive climate change impacts. Extreme drought will occur in the PRB resulting serious problem of a water scarcity, rather than floods. The future freshwater accessibility will be significantly declined for both the annual and seasonal flow due to serious consequence of drought risk. The significant decreases in both monthly 
and seasonal streamflow were projected by GISS-E2-R-CC which indicated the overall drier pattern. Furthermore, a decrease trend of $Q_{5}$ and $Q_{95}$ was projected by most GCMs for future period, showing that both the high flows and low flows will be lower than baseline flows. As stated by other regional studies, a change in the seasonal rainfall distribution, with overall drier and prolonged dry season, and precipitation decline occurring in the Lower Mekong Basin, largely attributed to likely decreases of future streamflow $[18,19,55]$. Besides the potential of climate change impacts, the hydropower and irrigation development also put high pressure on water resources in the PRB.

Land use has significantly changed in the PRB due to the deforestation at the upstream and the agriculture land expansions at the downstream. The static 2002 land-use and soil property data remained from the baseline period, which would inevitably lead to inaccurate results of future river flow prediction. In addition, the exclusion of water diversion for irrigation, industrial, domestic water supply during flow simulations in SWAT would result different effects of future streamflow change. The impacts of intensive irrigation activities on river discharge under agricultural scenarios would have been analyzed [56].

The effects of hydrological model structure and parameter uncertainties as well as ranges of values should not be neglected in model capability evaluation. The inadequate long-term meteorological and hydrological stations in the PRB, as well as the low accuracy of the discharge measurements for SWAT calibration significantly attribute to the uncertainties of future flow projections. Therefore, the combined effects of climate and land use change could significantly decrease river flows within the basin. Further studies are required to evaluate the possible effects of climate change contributed to the future change in land use on river flows in the PRB.

\subsection{Water Demand and Supply Relations in Current Scenario}

SWAT-WEAP integrated approach was adopted to provide an effective method for technical evaluating the water resources management. The evaluation of water stress under E-flow maintenance, management options, and climate change scenarios considered both the water demand and supply in the modeling system. The WEAP model performance in this study was based on the accuracy of input data such as streamflow generated from SWAT and the units of irrigation water demand manually calculated by using formula along with long term period of meteorological data. This study indicates that high pressure of water resource management in the PRB is mostly derived from agricultural irrigation. In the last few decades, many irrigation schemes have been constructed for irrigation purpose in response to the agricultural land expansions and growing double crop lands. The integrated modeling finding suggests that building more reservoirs is the optimal solution to fulfill current water demands during dry season. Based on field survey, farmers constantly mentioned the problem of water shortage during the dry season. It can be concluded that current problem is not only caused by the physical water shortage, but also by a shortage of appropriate irrigation infrastructure and poor management for conveying irrigation services effectively to the farmers, and the lack of coordination between upstream and downstream water users. The result conclusions were in agreement with findings of Chem and Someth [54]. In order to reduce agricultural water use, demand management should also be considered. In response to actual problems raised by farmers, changing cropping patterns and structures and improving irrigation efficiency technologies would be more effective to solve current water shortage problems. In addition to supply management, proper irrigation infrastructures should be improved immediately to enhance efficiency in delivering water to farmlands.

\subsection{Climate Change Impacts on Water Demand and Supply Relations}

Future climate change is expected to increase variability of temperature and precipitation attributed to result in a severe drought in both magnitude and frequency. Increasing in temperatures normally augment evaporative demand leading to higher crop evapotranspiration. In addition, the climate change impacts outweigh the effects of precipitation increase, significantly attributed to the increase of future IWD. The overall monthly increase of IWD will be substantial greater than $20 \%$ for all 
GCMs. The future streamflow will be reduced resulting the decline of water availability during both wet and dry season from 2051 to 2070 under all GCMs. This study found that the future water unmet demand will be more noticeable under E-flows maintenance if the additional reservoir storage was not included. Without a reservoir, the UD will increase for all climate change scenarios. However, by considering reservoirs, non-significant of UD has been observed. It can be concluded that during continuous drought under climate change condition, reservoirs will play a crucial role in alleviating water shortage problem. The planning strategies of reservoir construction would be necessary for agriculture mitigation and adaptation to climate change. However, under the condition of an increasing irrigated area from 2025 and E-flows maintenance, the reservoirs will not provide a sufficient amount of water for irrigation [57]. This indicates that a reservoir might reduce the current water shortages, but existing interests and actions of upstream and downstream areas seem to be more important. Building more reservoirs could attribute to high environment cost through the decrease of environmental flows threatening aquatic biodiversity in downstream ecosystem. In addition, there is also a high construction cost to construct more reservoirs. The water shortage issues will occur not only for dry season crops, but also for wet season crops from 2043. This study suggests that demand management will be an effective option for sustainable water resources management in the future period. The result suggestions are in accord with the studies on analysis of current and future water demands under sustainable management [2,52]. For reducing the water resources vulnerability and dealing with climate change impacts, the adaptation measures from demand side management (i.e., altering growing schedule, improving irrigation efficiency) will be effective in the context of sustainable management. Various studies have examined the effective technologies and adaptation measures of irrigation management which could fulfill the demand under the impacts of climate change $[6,58,59]$. This study suggests that water resources management options considering both supply and demand management are more effective and useful than supply management only, particularly in dealing with climate change impacts.

\section{Conclusions}

The driven forces derived from rapid urbanization, an increasing population, economic development, and substantial alteration to the hydrological process under climate change conditions have put high pressure on water resources management in the PRB. The predictive tool developments for supporting a better understand and management of water resources in the PRB were made by considerable efforts in this research. This study adopted the integrated modeling approach to operationally assess the impact of climate change on supply and demand relations under E-flows maintenance and management options. Firstly, SWAT was assisted to generate the future change of monthly streamflow for the future period 2051-2070. Water supply and demand relations were conducted by a water balance simulation model (WEAP). These simulations provided valuable insights about water resources allocation, projected water demand under water resources infrastructure development (i.e., reservoirs) and climate change conditions. Results from the water balance model were evaluated by the accuracy of input data and field survey.

This study indicated that the future freshwater accessibility will be declined significantly in both the annual and seasonal flow due to serious consequence of drought risk under climate change impacts. The significant decreases in streamflow were projected by GISS-E2-R-CC which indicated the overall drier pattern. Without reservoir and E-flows in $S_{I}$ and $S_{E}$, the availability of water could not meet the demand requirements in the lowest part of PRB, and the neighboring catchments. However, with reservoir and E-flows in $\mathrm{S}_{\mathrm{II}}$ and $\mathrm{S}_{\mathrm{IE}}$, additional flows from reservoir storage would support all existing and planned irrigation schemes inside the PRB and neighboring catchments. On the other hand, building more reservoirs is the optimal solution to fulfill current water demands during continuous drought under future climate change condition. This study suggests that water resources management options considering both supply and demand management are more effective and useful than supply management only, particularly in dealing with climate change impacts. Model researches are required 
to analyze the effectiveness of suitable irrigation management applications that can support crop water demands under climate change condition in the PRB. The assessment of combined impacts of extensive irrigation demand and climate change on river discharge should be conducted together for future streamflow predictions. Further studies are also required to study the accessibility of possible groundwater for water allocation and planning in the PRB.

Author Contributions: T.T. conducted the modelling, analysed the results, and wrote the paper. C.O. and Y.J. supervised the research, advised on the methodologies, gave comments, and corrected the manuscript. A.M. gave comments and improved the manuscript. All authors have read and agreed to the published version of the manuscript.

Funding: This study was funded by a grant from Chinese Scholarship Council (CSC).

Acknowledgments: The authors would like to thank the Mekong River Commission and Japan International Cooperation Agency for providing datasets, and particularly for Stockholm Environment Institute for providing a free license of WEAP model. The authors would also like to thank the anonymous reviewers and the editor for providing valuable comments which helped improve this manuscript.

Conflicts of Interest: The authors declare no conflict of interest.

\section{References}

1. Ty, T.V.; Sunada, K.; Ichikawa, Y.; Oishi, S. Scenario-based Impact Assessment of Land Use/Cover and Climate Changes on Water Resources and Demand: A Case Study in the Srepok River Basin, Vietnam-Cambodia. Water Resour. Manag. 2012, 26, 1387-1407. [CrossRef]

2. Amin, A.; Iqbal, J.; Asghar, A.; Ribbe, L. Analysis of Current and Future Water Demands in the Upper Indus Basin under IPCC Climate and Socio-Economic Scenarios Using a Hydro-Economic WEAP Model. Water 2018, 10, 537. [CrossRef]

3. IPCC. Climate Change 2013: The Physical Science Basis. Contribution of Working Group I to the Fifth Assessment Report of the Intergovernmental Panel on Climate Change; Cambridge University Press: Cambridge, UK; New York, NY, USA, 2013; pp. 19-20.

4. Reshmidevi, T.V.; Nagesh Kumar, D.; Mehrotra, R.; Sharma, A. Estimation of the climate change impact on a catchment water balance using an ensemble of GCMs. J. Hydrol. 2018, 556, 1192-1204. [CrossRef]

5. Muttiah, R.S.; Wurbs, R.A. Modeling the Impacts of Climate Change on Water Supply Reliabilities. Water Int. 2002, 27, 407-419. [CrossRef]

6. Ahmadaali, J.; Barani, G.-A.; Qaderi, K.; Hessari, B. Analysis of the Effects of Water Management Strategies and Climate Change on the Environmental and Agricultural Sustainability of Urmia Lake Basin, Iran. Water 2018, 10, 160. [CrossRef]

7. Zhou, Y.; Ching, L. Embedding Innovation: Bricolage and the Case of the Phnom Penh Water Supply Authority. In Institutional Entrepreneurship and Policy Change: Theoretical and Empirical Explorations; Bakir, C., Jarvis, D.S.L., Eds.; Springer International Publishing: Cham, Switzerland, 2018; pp. 221-242. [CrossRef]

8. Leong, C. Ek Sonn Chan and the Transformation of the Phnom Penh Water Supply Authority. Ssrn Electron. J. 2010. [CrossRef]

9. Dore, J.; Lebel, L. Deliberation and Scale in Mekong Region Water Governance. Environ. Manag. 2010, 46, 60-80. [CrossRef]

10. World Bank. World Development Report 2010: Development and Climate Change; World Bank: Washington, DC, USA, 2010.

11. IPCC. Climate Change 2007: Impacts, Adaptation and Vulnerability. Contribution of Working Group II to the Fourth Assessment Report of the IPCC.; Cambridge University Press: Cambridge, UK, 2007.

12. Mertz, O.; Halsnæs, K.; Olesen, J.; Rasmussen, K. Adaptation to Climate Change in Developing Countries. Environ. Manag. 2009, 43, 743-752. [CrossRef]

13. Arief Anshory, Y.; Herminia, F. Climate Change Vulnerability Mapping for Southeast Asia; Economy and Environment Program for Southeast Asia (EEPSEA): South Bridge Court, Singapore, 2009.

14. Wada, Y.; Wisser, D.; Eisner, S.; Flörke, M.; Gerten, D.; Haddeland, I.; Hanasaki, N.; Masaki, Y.; Portmann, F.T.; Stacke, T. Multimodel projections and uncertainties of irrigation water demand under climate change. Geophys. Res. Lett. 2013, 40, 4626-4632. [CrossRef] 
15. Frederick, K.D.; Major, D.C. Climate Change and Water Resources. In Climate Change and Water Resources Planning Criteria; Frederick, K.D., Major, D.C., Stakhiv, E.Z., Eds.; Springer: Dordrecht, The Netherlands, 1997; pp. 7-23. [CrossRef]

16. Kirby, J.M.; Mainuddin, M.; Mpelasoka, F.; Ahmad, M.D.; Palash, W.; Quadir, M.E.; Shah-Newaz, S.M.; Hossain, M.M. The impact of climate change on regional water balances in Bangladesh. Clim. Chang. 2016, 135, 481-491. [CrossRef]

17. Rowshon, M.K.; Dlamini, N.S.; Mojid, M.A.; Adib, M.N.M.; Amin, M.S.M.; Lai, S.H. Modeling climate-smart decision support system (CSDSS) for analyzing water demand of a large-scale rice irrigation scheme. Agric. Water Manag. 2019, 216, 138-152. [CrossRef]

18. Oeurng, C.; Cochrane, T.A.; Chung, S.; Kondolf, M.G.; Piman, T.; Arias, M.E. Assessing Climate Change Impacts on River Flows in the Tonle Sap Lake Basin, Cambodia. Water 2019, 11, 618. [CrossRef]

19. Ngo, L.A.; Masih, I.; Jiang, Y.; Douven, W. Impact of reservoir operation and climate change on the hydrological regime of the Sesan and Srepok Rivers in the Lower Mekong Basin. Clim. Chang. 2018, 149, 107-119. [CrossRef]

20. Ng, G.-H.C.; McLaughlin, D.; Entekhabi, D.; Scanlon, B.R. Probabilistic analysis of the effects of climate change on groundwater recharge. Water Resour. Res. 2010, 46. [CrossRef]

21. Yaykiran, S.; Cuceloglu, G.; Ekdal, A. Estimation of Water Budget Components of the Sakarya River Basin by Using the WEAP-PGM Model. Water 2019, 11, 271. [CrossRef]

22. Lu, H.; Ge, S.; Yongqiang, L.; Hong, Q. Integrated modeling of water supply and demand under management options and climate change scenarios in Chifeng City, China. Jawra J. Am. Water Resour. Assoc. 2015, 51, 655-671. [CrossRef]

23. Maliehe, M.; Mulungu, D.M.M. Assessment of water availability for competing uses using SWAT and WEAP in South Phuthiatsana catchment, Lesotho. Phys. Chem. Earth 2017, 100, 305-316. [CrossRef]

24. Neitsch, S.L.; Arnold, J.G.; Kiniry, J.R.; Williams, J.R.; King, K.W. Soil and Water Assessment Tool Theoretical Documentation, Ver. 2009; Blackland Research Center, Texas Agricultural Experiment Station: Temple, TX, USA, 2011.

25. Yates, D.; Sieber, J.; Purkey, D.; Huber-Lee, A. WEAP21-A demand-, priority-, and preference-driven water planning model: Part 1: Model characteristics. Water Int. 2005, 30, 487-500. [CrossRef]

26. CNMC. Profile of the Tonle Sap Sub-area (SA-9C); Cambodia National Mekong Committee: Phnom Penh, Cambodia, 2012.

27. JICA. Brief Progress Report on the Water Balance Examination Study for Pursat and Baribor River Basins; Japan International Cooperation Agency: Yokosuka, Japan; Ministry of Water Resources and Meteorology: Phnom Penh, Cambodia, 2013.

28. JICA. Misahiko H. Report on Examination of Impact of New Dam Plans on the West Tonle Sap Irrigation Rehabilitation Projects in Pursat River Basin; Japan International Cooperation Agency: Yokosuka, Japan; Ministry of Water Resources and Meteorology: Phnom Penh, Cambodia, 2011.

29. JICA. Land Use Map of Cambodia; Japan International Cooperation Agency: Tokyo, Japan, 2002.

30. MK16. Fostering Evidence-Based IWRM in Stung Pursat Catchment (Tonle Sap Great Lake) Cambodia; Hatfield Consultants and CEPA: British Columbia, BC, Canada; Ministry of Water Resources and Meteorology: Phnom Penh, Cambodia, 2013.

31. JICA. Water Balance Examination Study on Pursat and Baribor River Basins; Japan International Cooperation Agency: Yokosuka, Japan; Ministry of Water Resources and Meteorology: Phnom Penh, Cambodia, 2013.

32. MOWRAM. Feasibility Study on Stung Pursat Dam No. 3 and No. 5 Development Project; Gangdong Foreign Construction Company Ltd.: Seoul, Korea; Ministry of Water Resources and Meteorology: Phnom Penh, Cambodia, 2010.

33. MIME. Stung Pursat 1: Hydroelectric Project. In Proceedings of the 1st MSP Meeting, Buenos Aires, Argentina, 24-25 January 2015.

34. Ang, R.; Oeurng, C. Simulating Streamflow in an Ungauged Catchment of Tonlesap Lak Basin Using Soil and Water Assessment Tool (SWAT) Model. Water Sci. 2018. [CrossRef]

35. JICA. Special Assistance for Project Implementation for West Tonle Sap Irrigation and Drainage Rehabilitation and Improvement Project in the Kingdom of Cambodia; Japan International Coorperation Agency: Phnom Penh, Cambodia, 2012.

36. Allen, R.G.; Pereira, L.S.; Raes, D.; Smith, M. Crop Evapotranspiration (Guidelines for Computing Crop Water Requirements); United Nations Food and Agriculture Organization: Rome, Italy, 1998. 
37. Blaney, H.F.; Griddle, W.D. Determining consumptive use and irrigation water requirements. Tech. Bull. 1962, 25, 369-373.

38. National Institute of Statistics. General Population Census of Cambodia 2008; Ministry of Planning: Phnom Penh, Cambodia, 2008.

39. Oeurng, C.; Sauvage, S.; Sánchez-Pérez, J.-M. Temporal variability of nitrate transport through hydrological response during flood events within a large agricultural catchment in south-west France. Sci. Total Environ. 2010, 409, 140-149. [CrossRef] [PubMed]

40. Arnold, J.G.; Allen, P.M.; Bernhardt, G. A comprehensive surface-groundwater flow model. J. Hydrol. 1993, 142, 47-69. [CrossRef]

41. Priestley, H.B.; Taylor, R.J. On the Assessment of Surface Heat Flux and Evaporation Using Large Scale Parameters. Mon. Weather Rev. 1972, 100, 81-92. [CrossRef]

42. Monteith, J.L. Evaporation and environment. Symp. Soc. Exp. Biol. 1965, 19, 205-234.

43. Hargreaves, G.H.; Samani, Z. Reference Crop Evapotranspiration from Temperature. Appl. Eng. Agric. 1985, 1, 96-99. [CrossRef]

44. Sieber, J.; Purkey, D. User Guide for WEAP 21; SEI [Stockholm Environment Institute]: Somerville, MA, USA, 2005.

45. MRC. 1st Draft Report on Defining Basin-Wide Climate Change Scenarios for the Lower Mekong Basin; Mekong River Commission: Vientiane, Laos, 2015.

46. Shrestha, B.; Cochrane, T.A.; Caruso, B.S.; Arias, M.E.; Piman, T. Uncertainty in flow and sediment projections due to future climate scenarios for the 3 S Rivers in the Mekong Basin. J. Hydrol. 2016, 540, 1088-1104. [CrossRef]

47. Oeurng, C.; Cochrane, T.A.; Arias, M.E.; Shrestha, B.; Piman, T. Assessment of changes in riverine nitrate in the Sesan, Srepok and Sekong tributaries of the Lower Mekong River Basin. J. Hydrol. Reg. Stud. 2016, 8, 95-111. [CrossRef]

48. Dufresne, J.-L.; Foujols, M.-A.; Denvil, S.; Caubel, A.; Marti, O.; Aumont, O.; Balkanski, Y.; Bekki, S.; Bellenger, H.; Benshila, R.; et al. Climate change projections using the IPSL-CM5 Earth System Model: From CMIP3 to CMIP5. Clim. Dyn. 2013, 40, 2123-2165. [CrossRef]

49. Shindell, D.T.; Pechony, O.; Voulgarakis, A.; Faluvegi, G.; Nazarenko, L.; Lamarque, J.F.; Bowman, K.; Milly, G.; Kovari, B.; Ruedy, R.; et al. Interactive ozone and methane chemistry in GISS-E2 historical and future climate simulations. Atmos. Chem. Phys. 2013, 13, 2653-2689. [CrossRef]

50. Levy, H., II; Horowitz, L.W.; Schwarzkopf, M.D.; Ming, Y.; Golaz, J.-C.; Naik, V.; Ramaswamy, V. The roles of aerosol direct and indirect effects in past and future climate change. J. Geophys. Res. Atmos. 2013, 118, 4521-4532. [CrossRef]

51. Pastor, A.V.; Ludwig, F.; Biemans, H.; Hoff, H.; Kabat, P. Accounting for environmental flow requirements in global water assessments. Hydrol. Earth Syst. Sci. 2014, 18, 14987-15032. [CrossRef]

52. Sapkota, P.; Bharati, L.; Gurung, P.; Kaushal, N.; Smakhtin, V. Environmentally sustainable management of water demands under changing climate conditions in the Upper Ganges Basin, India. Hydrol. Process. 2013, 27, 2197-2208. [CrossRef]

53. Babel, M.S.; Nguyen Dinh, C.; Mullick, M.R.A.; Nanduri, U.V. Operation of a hydropower system considering environmental flow requirements: A case study in La Nga river basin, Vietnam. J. Hydro-Environ. Res. 2012, 6, 63-73. [CrossRef]

54. Chem, P.; Someth, P. Use of Hydrological Knowledge and Community Participation for Improving Decision-Making on Irrigation Water Allocation. Cdri Work. Pap. 2011, 59, 36-37.

55. Piman, T.; Cochrane, T.A.; Arias, M.E.; Dat, N.D.; Vonnarart, O. Managing Hydropower Under Climate Change in the Mekong Tributaries. In Managing Water Resources under Climate Uncertainty: Examples from Asia, Europe, Latin America, and Australia; Shrestha, S., Anal, A.K., Salam, P.A., van der Valk, M., Eds.; Springer International Publishing: Cham, Switzerland, 2015; pp. 223-248. [CrossRef]

56. Huang, S.; Krysanova, V.; Zhai, J.; Su, B. Impact of Intensive Irrigation Activities on River Discharge Under Agricultural Scenarios in the Semi-Arid Aksu River Basin, Northwest China. Water Resour. Manag. 2015, 29, 945-959. [CrossRef]

57. Swiech, T.; Ertsen, M.W.; Pererya, C.M. Estimating the impacts of a reservoir for improved water use in irrigation in the Yarabamba region, Peru. Phys. Chem. EarthParts A/B/C 2012, 47-48, 64-75. [CrossRef] 
58. Huang, S.; Wortmann, M.; Duethmann, D.; Menz, C.; Shi, F.; Zhao, C.; Su, B.; Krysanova, V. Adaptation strategies of agriculture and water management to climate change in the Upper Tarim River basin, NW China. Agric. Water Manag. 2018, 203, 207-224. [CrossRef]

59. Joyce, B.A.; Mehta, V.K.; Purkey, D.R.; Dale, L.L.; Hanemann, M. Modifying agricultural water management to adapt to climate change in California's central valley. Clim. Chang. 2011, 109, 299-316. [CrossRef]

(C) 2020 by the authors. Licensee MDPI, Basel, Switzerland. This article is an open access article distributed under the terms and conditions of the Creative Commons Attribution (CC BY) license (http://creativecommons.org/licenses/by/4.0/). 